\title{
Taxonomic and Ecological Study of the Families Hydrodictyaceae and Coelastraceae, Order Chlorococcales, and Class Chlorophyceae in Korea
}

\author{
Yong Jae Kim* \\ Department of Life Science, Daejin University, Pocheon 487-711, Korea
}

\begin{abstract}
A study on Chlorococcal algae was carried out at 33 stations (ponds, swamps, reservoirs, lakes and rivers) from May 2009 to January 2013. The families Hydrodictyaceae and Coelastraceae of order Chlorococcales were investigated, including 5 genera, 29 species, and 17 varieties. Among them, 8 taxa were newly recorded for Korea; 1) Family Hydrodictyaceae: Pediastrum asymmetricum, $P$. boryanum var. campanulatum, 2) Family Coelastraceae : Actinastrum aciculare, A. hantzschii var. subtile, Coelastrum indicum, C. microporum var. octaedricum, C. morus, C. pulchrum.
\end{abstract}

Key words: Chlorococcal algae, Chlorococcales, Coelastraceae, Hyrodictyaceae, Korea, newly recorded

\section{INTRODUCTION}

Freshwater green algae (Chlorophyta) are characterized as the largest and most varied algal phylum. The freshwater green algae have great diversity in their cellular organization, morphological structure, and reproductive processes than that of any other algae (Bold et al. 1978). They are closely related to the higher plants in phylogenetic, which have similar structures in their chloroplasts, and photosynthetic pigments (chlorophyll-a, b and carotenoids) and store of starch (e.g., pyrenoid). Green algae comprise 7 orders (i.e., Volvocales, Tetrasporales, Chlorococcales, Microsporales, Chaetophorales, Oedogoniales and Zygnematales), but one of the orders, Zygnematales is separated into the Class Zygnematophyceae from Chlorophyceae by some researchers (Round 1971, Kenrick and Crane 1997).

The Chlorococcales are a large number of species, which are predominantly aquatic system and have the widest distribution among the Chlorophyceae. Chlo- rococcal algae are mostly unicellular or may form colonies of a definite shape (Prescott 1962). They occur in the plankton and benthos of mesotrophic or eutrophic waters, and are the most diverse with the highest abundance. From the spring to fall, in particular, their reproduction is extensive such that they impart a green vegetation-like color to the water (Hindak 1977). Thus, they play an important role in the primary and secondary successional processes (John and Tsarenko 2002).

Studies of freshwater algae in Korea were begun by Kawamura (1918). He first reported the genus Cenritractus in Lake Suwon Seoho. Since then, 58 taxa including 1 new species and 1 new variety from Lake Suwon Seoho have been reported by Skvortzow (1929). Ueno (1940) investigated and reported the taxa in Lake Bujeon, swamp Daetaek, the Aprok river, the upper reach of Namdaecheon stream and Jooeul hot springs. Previous studies on the flora and taxonomy of freshwater algae in Korea were http://dx.doi.org/10.5141/ecoenv.2013.421

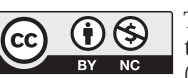

This is an Open Access article distributed under the terms of the Creative Commons Attribution Non-Commercial Licens (http://creativecommons.org/licenses/by-nc/3.0/) which permits unrestricted non-commercial use, distribution, and reproduction in any medium, provided the original work is properly cited.
Received 29 October 2013, Accepted 12 November 2013

*Corresponding Author

E-mail: yjkim@daejin.ac.kr

Tel: +82-31-539-1851 
conducted by a few foreign scholars (Kawamura 1918, Skvortzow 1929, 1932, Yamaguchi 1941, Ueno 1942, Emoto and Hirose 1942, Yamamoto 1941). Subsequently, Korean florists reported previously the unreported freshwater algae in Korea from reservoirs, dam lakes, hot springs and other area (Chung and Chang 1957, Kim and Chang 1958, Chung 1968, 1974, 1978, 1981, Chung and Kim 1991, 1992, Chung et al. 1972, Kim et al. 1991, 1994).

The family Hydrodictyaceae includes coccal green algae, which have microscopic, flat, spherical and circular coenobium. However, the Hydrodictyon species form a net and are benthos. The genera Pediastrum and Sorastrum belong to a family that is characterized by the formation of coenobia, which are composed of a characteristic arrangement of cells, morphology of cells, and particular sculptures on the outer cell wall (Komarek and Jankovska 2001). The family Coelastraceae is also a coccal green algae, which is arranged 3 dimensionally and is spherical (e.g., genus Coelastraceae) or radiating from a center (e.g., genus Actinastrum).

The reported taxa belonging to the family Hydrodictyaceae and Coelastraceae in Korea represent 6 genera and 49 taxa, which include the genus Pediastrum (30 taxa), Sorastrum (3taxa), Hydrodictyon (1 taxon), Coelastrum (9 taxa), Actinastrum (1 taxon) and Ducelleria (1 taxon). The genus Ducelleria was not recorded in this study.

The purpose of this study was to newly record some taxa of the families Hydrodictyaceae and Coelastraceae, order Chlorococcales, and class Chlorophyceae representing 5 genera and 46 taxa from the swamps, ponds, reservoirs, lakes and rivers in Korea (Table 1). Herein I presented the detailed taxonomic information, illustrations, classification, references, synonyms, basionyms and distribution in Korea.

\section{MATERIAL AND METHODS}

The samples of Chlorococcal algae were collected at 33 stations including ponds, swamp, reservoirs, lakes and rivers from May 2009 to April 2013 (Table 1). Sampling stations were located throughout the country. All samples were collected using $10 \mu \mathrm{m}$ or $20 \mu \mathrm{m}$ mesh-sized plankton nets with vertical and/or horizontal towing, or submerged benthic or soil algae with spoid or brush. Chlorococcal algae samples were immediately fixed with Lugol's iodine solution $(0.5 \%)$ for immobilizing the cells to facilitate microscopic examination. To examine the fine structures and cellular shapes, and to identify and classify the
Chlorococcal species, a temporary slide was made using the follow steps: 1) the phytoplankton samples (Chloroccocal algae) were mixed with glycerin in micro tubes. 2) The mixed samples were placed, drop-wise on slide glass, and were fixed in position with cover slides. Permanent slides were made using the follow steps: 1) the phytoplankton samples (Chloroccocal algae) were mixed with liquid glycerol gelatin for mounting histochemical slides (Sigma-Aldrich, St. Louis, MO, USA). 2) The mixed sample was placed drop-wise on slide glass and was fixed in position with a cover slide. 3) it was cemented the margin of a cover glass with manicure (Thecashop, Seoul, Korea). The temporary and permanent slides were observed at $\times 200$ to $\times 1,600$ magnification using light microscopy (LM) (Axioskop 20 and Axio Imager A2; Carl Zeiss, Oberkochen, Germany) with an attached digital camera (Axiocam HRc; Carl Zeiss) being used to capture images. Asterisk mark (*) indicates taxa which are new to Korea.

At each station, physical and chemical factors of water were recorded during the sampling periods. Water temp. (water temperature) and EC (electric conductivity) was measured in situ using a portable thermometer and EC meter (Orion 5-star; Thermo Scientific, Waltham, MA, USA) and a $\mathrm{pH}$ was measured in situ using a pH meter (Ultrabasic-5; Denver Instrument, Bohemia, NY, USA) respectively. This study used the data of total nitrogen (TN) and total phosphate (TP) concentrations at each sampling station from the water information system of the Ministry of Environment (NIER 2013).

Chlorococcal algae identification were mainly based on Komarek and Fott (1983), John and Tsarenko (2002), Hindak (1977), Prescott (1962), Hirose and Yamagishi (1977) and Yamagishi and Akiyama (1984 - 1997).

\section{RESULTS AND DISCUSSION}

The families Hydrodictyaceae and Coelastraceae, order Chlorococcales, class Chlorophyceae are composed of 5 genera, 29 species, and 17 varieties in this study based on Komarek and Fott (1983), Parra (1979) and Komarek and Jankovska (2001). 8 taxa of these families were newly recorded in Korea: Pediastrum asymmetricum, P. boryanum var. campanulatum, Coelastrum microporum var. octaedricum, C. morus, C. indicum, C. pulchrum, Actinastrun hantzschii var. subtile, and A. aciculare.

This study detailed taxonomic information, illustrations, classification, references, basionyms, synonyms and distribution of newly recorded taxa of these families. 
Table 1. Sampling sites of the families Hydrodictyaceae and Coelastraceae, order Chlorococcales 2009-2013.

\begin{tabular}{|c|c|c|c|}
\hline Station & Collected data & Locality & Coordinate \\
\hline Dongchang stream & 13 May 2009 & Unmun, Cheongdo, Gyeongsangbuk-do & $\begin{array}{l}35^{\circ} 50^{\prime} 34^{\prime \prime} \mathrm{N}, \\
128^{\circ} 44^{\prime} 43^{\prime \prime} \mathrm{E}\end{array}$ \\
\hline Estuary Dam of Geumgang river & 05 May 2011, 07 Oct 2011 & Seongduk, Goonsan, Jeollabuk-do & $\begin{array}{l}36^{\circ} 00^{\prime} 59^{\prime \prime} \mathrm{N}, \\
126^{\circ} 44^{\prime} 55^{\prime \prime} \mathrm{E}\end{array}$ \\
\hline Nakdong river & 10 Aug 2011, 25 Oct 2011 & Gilgok, Changnyeong, Gyeongsangnam-do & $\begin{array}{l}35^{\circ} 23^{\prime} 26^{\prime \prime} \mathrm{N}, \\
128^{\circ} 35^{\prime} 51^{\prime \prime} \mathrm{E}\end{array}$ \\
\hline Pond of Daejin university & 29 Aug 2011 & Seondan, Pocheon, Gyeonggi-do & $\begin{array}{l}37^{\circ} 52^{\prime} 29^{\prime \prime} \mathrm{N}, \\
127^{\circ} 09^{\prime} 28^{\prime \prime} \mathrm{E}\end{array}$ \\
\hline Donghwa stream & 24 Sep 2011 & Bibong, Hwaseong, Gyeonggi-do & $\begin{array}{l}37^{\circ} 15^{\prime} 23^{\prime \prime} \mathrm{N}, \\
126^{\circ} 53^{\prime} 07^{\prime \prime} \mathrm{E}\end{array}$ \\
\hline Samrak park & 03 Nov 2011 & Samrakg, Sasang, Busan & $\begin{array}{l}35^{\circ} 10^{\prime} 09^{\prime \prime} \mathrm{N}, \\
128^{\circ} 58^{\prime} 06^{\prime \prime} \mathrm{E}\end{array}$ \\
\hline Lake Baekwun & 02 Sep 2011 & Cheonggy, Uiwang, Gyeonggi-do o & $\begin{array}{l}37^{\circ} 22^{\prime} 33^{\prime \prime} \mathrm{N}, \\
127^{\circ} 00^{\prime} 17^{\prime \prime} \mathrm{E}\end{array}$ \\
\hline Lake Pomun & 10 Sep 2011, 21 Jan 2012 & Boduk, Gyeongju, Gyeongsangbuk-do & $\begin{array}{l}35^{\circ} 50^{\prime} 20^{\prime \prime} \mathrm{N}, \\
129^{\circ} 16^{\prime} 45^{\prime \prime} \mathrm{E}\end{array}$ \\
\hline Lake Bongpo & 15 Aug 2011 & Toseong, Goseong, Gangwon-do & $\begin{array}{l}38^{\circ} 14^{\prime} 27^{\prime \prime} \mathrm{N}, \\
128^{\circ} 34^{\prime} 08^{\prime \prime} \mathrm{E}\end{array}$ \\
\hline Bukhan river & 17 Dec 2011 & Hwado, Namyangju, Gyeonggi-do & $\begin{array}{l}37^{\circ} 40^{\prime} 20^{\prime \prime} \mathrm{N}, \\
127^{\circ} 34^{\prime} 00^{\prime \prime} \mathrm{E}\end{array}$ \\
\hline Lake Seoho & 03 Sep 2011, 20 Nov 2011 & Hwaseo, Suwon, Gyeonggi-do & $\begin{array}{l}37^{\circ} 16^{\prime} 40^{\prime \prime} \mathrm{N}, \\
126^{\circ} 59^{\prime} 15^{\prime \prime} \mathrm{E}\end{array}$ \\
\hline Lake 88 & 07 Sep 2011 & Olympic park, Bang-I, Songpa, Seoul & $\begin{array}{l}37^{\circ} 31^{\prime} 14^{\prime \prime} \mathrm{N}, \\
127^{\circ} 07^{\prime} 03^{\prime \prime} \mathrm{E}\end{array}$ \\
\hline Wangsong reservoir & 03 Sep 2011 & Bugok, Uiwang, Gyeonggi-do & $\begin{array}{l}37^{\circ} 18^{\prime} 05^{\prime \prime} \mathrm{N}, \\
127^{\circ} 56^{\prime} 09^{\prime \prime} \mathrm{E}\end{array}$ \\
\hline Fishery of Ugeum & $\begin{array}{l}29 \text { May 2011, } 29 \text { Aug 2011, } \\
31 \text { Oct 2011, } 21 \text { Jul } 2012\end{array}$ & Gansan, Pocheon, Gyeonggi-do & $\begin{array}{l}37^{\circ} 49^{\prime} 33^{\prime \prime} \mathrm{N}, \\
127^{\circ} 12^{\prime} 39^{\prime \prime} \mathrm{E}\end{array}$ \\
\hline Ugeum reservoir & $\begin{array}{l}29 \text { May 2011, } 29 \text { Aug 2011, } \\
31 \text { Oct 2011, } 21 \text { Jul } 2012\end{array}$ & Gansan, Pocheon, Gyeonggi-do & $\begin{array}{l}37^{\circ} 49^{\prime} 40^{\prime \prime} \mathrm{N}, \\
127^{\circ} 12^{\prime} 41^{\prime \prime} \mathrm{E}\end{array}$ \\
\hline Ilgam reservoir & 19 Dec 2011 & Jayang, Gwangjin, Seoul & $\begin{array}{l}37^{\circ} 32^{\prime} 26^{\prime \prime} \mathrm{N}, \\
127^{\circ} 04^{\prime} 35^{\prime \prime} \mathrm{E}\end{array}$ \\
\hline Ilwang reservoir & 03 Sep 2011 & Songchuk, Suwon, Gyeonggi-do & $\begin{array}{l}37^{\circ} 17^{\prime} 59^{\prime \prime} \mathrm{N}, \\
127^{\circ} 00^{\prime} 02^{\prime \prime} \mathrm{E}\end{array}$ \\
\hline Ilweol reservoir & 29 Aug 2011 & Jincheon, Suwon, Gyeonggi-do & $\begin{array}{l}37^{\circ} 17^{\prime} 09^{\prime \prime} \mathrm{N}, \\
126^{\circ} 58^{\prime} 26^{\prime \prime} \mathrm{E}\end{array}$ \\
\hline Jangcheok swamp & 15 Aug 2011 & $\begin{array}{l}\text { Shinje, Youngsan, Changnyeong, } \\
\text { Gyeongsangnam-do }\end{array}$ & $\begin{array}{l}35^{\circ} 26^{\prime} 01^{\prime \prime} \mathrm{N}, \\
128^{\circ} 29^{\prime} 54^{\prime \prime} \mathrm{E}\end{array}$ \\
\hline Pond of Jungang Park & 30 Oct 2011 & $\begin{array}{l}\text { Sunae, Bundang, Seongnam, } \\
\text { Gyeonggi-do }\end{array}$ & $\begin{array}{l}37^{\circ} 22^{\prime} 30^{\prime \prime} \mathrm{N}, \\
127^{\circ} 07^{\prime} 32^{\prime \prime} \mathrm{E}\end{array}$ \\
\hline Pond of KAIST & $\begin{array}{l}28 \text { Aug 2011, } 18 \text { Dec 2011, } \\
28 \text { May 2012 }\end{array}$ & Guseong, Yuseong, Daejeon & $\begin{array}{l}36^{\circ} 22^{\prime} 05^{\prime \prime} \mathrm{N}, \\
127^{\circ} 21^{\prime} 44^{\prime \prime} \mathrm{E}\end{array}$ \\
\hline Lake Paldang & 22 Aug 2011 & Joan, Namyangju, Gyeonggi-do & $\begin{array}{l}37^{\circ} 30^{\prime} 53^{\prime \prime} \mathrm{N}, \\
127^{\circ} 18^{\prime} 03^{\prime \prime} \mathrm{E}\end{array}$ \\
\hline Bukhan river & 26 Aug 2012 & Yangsoori, Yangpyeong, Gyeonggi-do & $\begin{array}{l}37^{\circ} 32^{\prime} 25^{\prime \prime} \mathrm{N} \\
127^{\circ} 18^{\prime} 47^{\prime \prime} \mathrm{E}\end{array}$ \\
\hline Lake Cheongpung & 31 Aug 2012 & $\begin{array}{l}\text { Cheongpung, Jecheon, } \\
\text { Chungcheongbuk-do }\end{array}$ & $\begin{array}{l}37^{\circ} 06^{\prime} 33^{\prime \prime} \mathrm{N}, \\
128^{\circ} 10^{\prime} 36^{\prime \prime} \mathrm{E}\end{array}$ \\
\hline Fishery of Giljeong & 30 May 2012 & Giljeongri, Yangdo, Ganghwa, Incheon & $\begin{array}{l}37^{\circ} 39^{\prime} 44^{\prime \prime} \mathrm{N}, \\
126^{\circ} 28^{\prime} 01^{\prime \prime} \mathrm{E}\end{array}$ \\
\hline Giljeong reservoir & 30 May 2012 & Giljeongri, Yangdo, Ganghwa, Incheon & $\begin{array}{l}37^{\circ} 39^{\prime} 32^{\prime \prime} \mathrm{N}, \\
126^{\circ} 28^{\prime} 04^{\prime \prime} \mathrm{E}\end{array}$ \\
\hline Dongmyeong reservoir & $10 \mathrm{Jul} 2012$ & $\begin{array}{l}\text { Gudeokri, Dongmyeon, Chilgok, } \\
\text { Gyeongsangbuk-do }\end{array}$ & $\begin{array}{l}35^{\circ} 58^{\prime} 42^{\prime \prime} \mathrm{N}, \\
128^{\circ} 33^{\prime} 50^{\prime \prime} \mathrm{E}\end{array}$ \\
\hline Okgu reservoir & 22 Sep 2012 & Gaesa, Gunsan, Jeollabuk-do & $\begin{array}{l}35^{\circ} 55^{\prime} 34^{\prime \prime} \mathrm{N}, \\
126^{\circ} 38^{\prime} 50^{\prime \prime} \mathrm{E}\end{array}$ \\
\hline Oknye reservoir & 22 Sep 2012 & Gaesa, Gunsan, , Jeollabuk-do & $\begin{array}{l}34^{\circ} 19^{\prime} 34^{\prime \prime} \mathrm{N}, \\
126^{\circ} 37^{\prime} 24^{\prime \prime} \mathrm{E}\end{array}$ \\
\hline Estuary of the Mankyeong river & 22 Sep 2012 & Bokgyori, Daeya, Gunsan, Jeollaabuk-do & $\begin{array}{l}35^{\circ} 54^{\prime} 28^{\prime \prime} \mathrm{N}, \\
126^{\circ} 49^{\prime} 57^{\prime \prime} \mathrm{E}\end{array}$ \\
\hline Muncheon reservoir & 22 Sep 2012 & Hayang, Kyungsan, Gyeongsangbuk-do & $\begin{array}{l}35^{\circ} 53^{\prime} 56^{\prime \prime} \mathrm{N}, \\
128^{\circ} 50^{\prime} 33^{\prime \prime} \mathrm{E}\end{array}$ \\
\hline Dongbaekdongsan & 06 Apr 2013 & Seonhuel, Jocheon, Jehu & $\begin{array}{l}33^{\circ} 30^{\prime} 52^{\prime \prime} \mathrm{N}, \\
126^{\circ} 43^{\prime} 07^{\prime \prime} \mathrm{E}\end{array}$ \\
\hline
\end{tabular}




\section{Division Chlorophyta Class Chlorophyceae Order Chlorococcales Family Hydrodictyaceae}

\section{Genus Hydrodictyon Roth 1797}

\section{Hydrodictyon reticulatum (Linnaeus) Lagerheim 1883}

Colonies are macroscopic, with many cylindrical cells adjoined at their ends that formed a pentagonal or hexagonal closed cylindrical net. Cells are 5-15 $\mu \mathrm{m}$ in diameter, 15-70 $\mu \mathrm{m}$ long.

\section{Genus Pediastrum Meyen 1829}

\section{Pediastrum simplex Meyen 1829}

Colonies are circular to ellipsoid with large intercellular spaces. The marginal cells are Y- to T- shaped with a single horn-like process, the inner cells are Y- shaped. Cells are 6-30 $\mu \mathrm{m}$ in diameter, and 12-52 $\mu \mathrm{m}$ long.

Pediastrum simplex var. echinulatum Wittrock 1883 in Wittrock et Nordstedt 1883 (Fig. 1)

Synonym: Monactinium simplex var. echnulatum Perez et al. 2009.

Illustration: Colonies are mostly composed of 4-8, 16, 32cells. The cells are arranged in a plate, which is either continuous or contains intercellular spaces. The outer cells have one elongated outward pointing process, and an inner polygonal cell. The cell wall surface of each cell is ornamented with teeth-like protuberance. The outer cells are 10-57 $\mu$ s long, 6-38 $\mu$ s in diameter, and the inner cells are 6-40 $\mu \mathrm{m}$ long, 6-36 $\mu \mathrm{m}$ in diameter.

Information of sampling sites: This species inhabits in lakes and reservoirs as plankton, and is collected from Wangsong reservoir (03 Sep 2011: water temp. $25.0^{\circ} \mathrm{C}$, pH 6.7, EC $227 \mu \mathrm{sm}^{-1}$, TN $2.884 \mathrm{mg} \mathrm{L}^{-1}$, TP $0.094 \mathrm{mg} \mathrm{L}^{-1}$ ), Lake Geumgang (05 May 2011: water temp. 20.0 ${ }^{\circ} \mathrm{C}$, pH 8.5; EC $227 \mu \mathrm{sm}^{-1}$, TN $3.536 \mathrm{mg} \mathrm{L}^{-1}$, TP $0.089 \mathrm{mg} \mathrm{L}^{-1}$ ), Lake Seoho (03 Sep 2011: water temp. $24.1^{\circ} \mathrm{C}$, pH 7.3, EC 569 $\mu \mathrm{cm}^{-1}$, TN 6.515mg L-1, TP $0.278 \mathrm{mg} \mathrm{L}^{-1}$ ), Lake Pomun (10 Sep 2011: water temp. $20.3^{\circ} \mathrm{C}$, pH 7.3, EC $82 \mu \mathrm{cm}^{-1}$, TN $0.479 \mathrm{mg} \mathrm{L}^{-1}$, TP $\left.0.018 \mathrm{mg} \mathrm{L}^{-1}\right)$.

Key Reference: Wittrock and Nordstedt (1883).

Remark: This taxon has already been reported in Algal flora of Korea by Kim and Kim (2012).

\section{Pediastrum simplex var. biwaense Fukushima 1953}

Colonies are circular with large intercellular spaces. The marginal cells are concave with a single process, the inner cells are similar to marginal cell without a process. Cells are 7-20 $\mu \mathrm{m}$ in diameter, and 10-35 $\mu \mathrm{m}$ long.

Pediastrum simplex var. sturmii (Reinsch) Wolle 1887 (Fig. 2)

Basionym: Pediastrum sturmii Reinsch 1867.

Synonym: Pediastrum simplex var. crenulatum Prescott; Monoactinium simplex var. sturmii Reinsch.

Illustration: Colonies are composed of 8-16 cells. The cells are arranged in a ring around a central space with one or more interior cells and a number of peripheral cells, perforation. The central cells are convex, and the cell wall is smooth. Chloroplast is a parietal, with a large pyrenoid. Cells are 8-18 $\mu \mathrm{m}$ in diameter, 14-37 $\mu \mathrm{m}$ long.

Information of sampling sites: This species inhabits in lakes and reservoirs as plankton, and is collected from Wangsong reservoir(03 Sep 2011: water temp. $25.0^{\circ} \mathrm{C}, \mathrm{pH}$ 6.7, EC $227 \mu \mathrm{sm}^{-1}$, TN $2.884 \mathrm{mg} \mathrm{L}^{-1}$, TP $0.094 \mathrm{mg} \mathrm{L}^{-1}$ ), Lake Gumgang (05 May 2011: water temp. $20.0^{\circ} \mathrm{C}$, pH 8.5, EC $227 \mu \mathrm{cm}^{-1}$,TN $3.536 \mathrm{mg} \mathrm{L}^{-1}$, TP $0.089 \mathrm{mg} \mathrm{L}^{-1}$ ), Lake Seoho(03 Sep 2011: water temp. $24.1^{\circ} \mathrm{C}$, pH 7.3, EC $569 \mu \mathrm{s}$ $\mathrm{cm}^{-1}$, TN $6.515 \mathrm{mg} \mathrm{L}^{-1}$, TP $0.278 \mathrm{mg} \mathrm{L}^{-1}$ ), Lake Pomun (10 Sep 2011: water temp. $20.3^{\circ} \mathrm{C}$, pH 7.3, EC $82 \mu \mathrm{cm}^{-1}$, TN $0.479 \mathrm{mg} \mathrm{L}^{-1}$, TP $\left.0.018 \mathrm{mg} \mathrm{L}^{-1}\right)$.

Key Reference: Wolle (1887).

Remark: This taxon has already been reported in Algal flora of Korea by Kim and Kim (2012).

\section{*Pediastrum asymmetricum Hegewald et Yamagishi 1994 (Fig. 3) \\ Synonym: Monactinus asymmetricus (Yamagishi et E.Hegewald) E.Hegewald. \\ Illustration: Colonies are composed of 8-16 cells, circu-} lar in outline, nearly flat, with large perforations. The cells are arranged more or less radially. The marginal cells are elongated, slightly bent, in principle with four lobes, three of the lobes are connected to neighboring cells. The inner cells are rectangular to quadrate with concave sides and four lobes. The cell wall is smooth. Chloroplast is a parietal, with a large pyrenoid. Cells are 8-15 $\mu \mathrm{m}$ in diameter, 10-25 $\mu \mathrm{m}$ long.

Information of sampling sites: This species inhabits in ponds, lakes and reservoirs as plankton, and is collected from from pond at Jungang Park (31 Oct. 2011: no data of water temp., pH and EC), 88 lake in Olympic Park (07 Sep 2012: no data of water temp., pH and EC).

Key Reference: Hegewald and Yamagishi (1994).

\section{Pediastrum integrum Nägeli 1849}

Colonies are subcircular to ovoid. The outer sides of the 

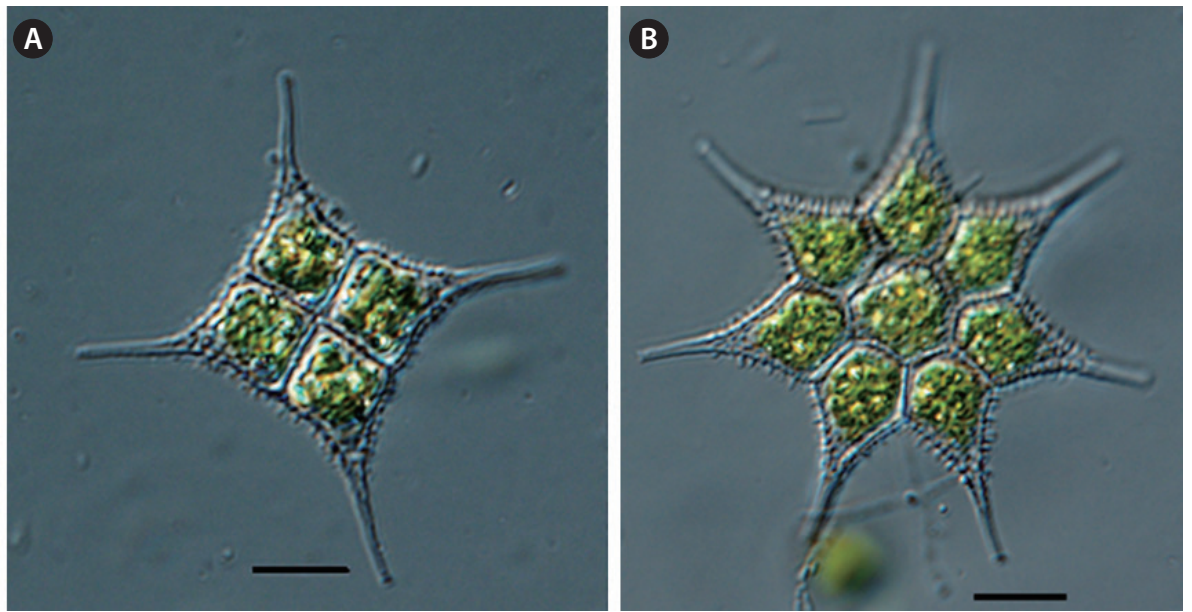

Fig. 1. Pediastrum simplex var. echinulatum Wittrock (A-B: each other colony). Scale bars, $10 \mu \mathrm{m}$.
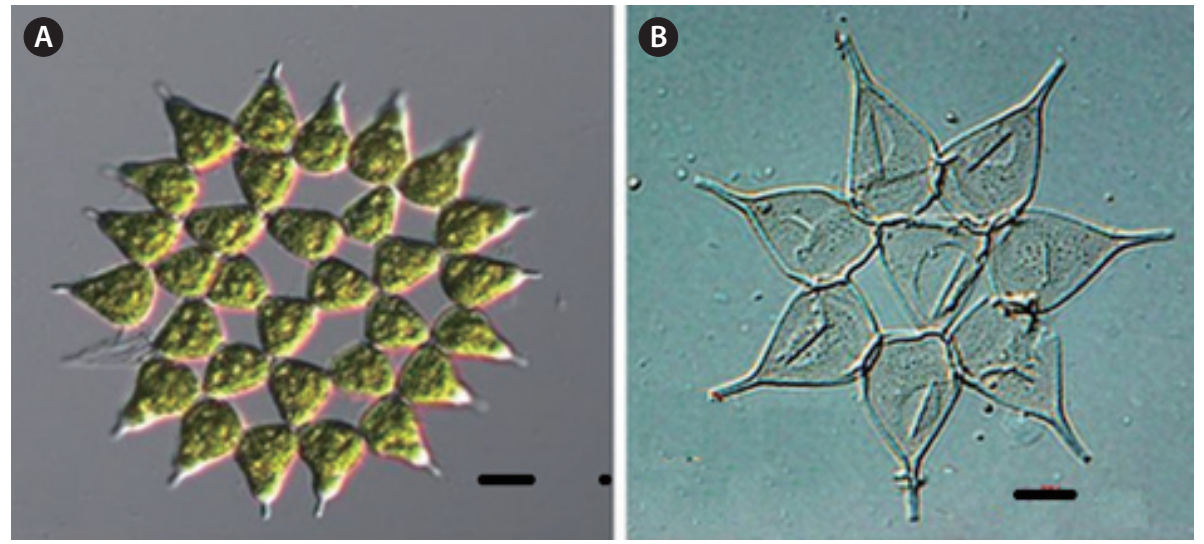

Fig. 2. Pediastrum simplex var. sturmii (Reinsch) Wolle (A-B: each other colony). Scale bars, $10 \mu \mathrm{m}$.
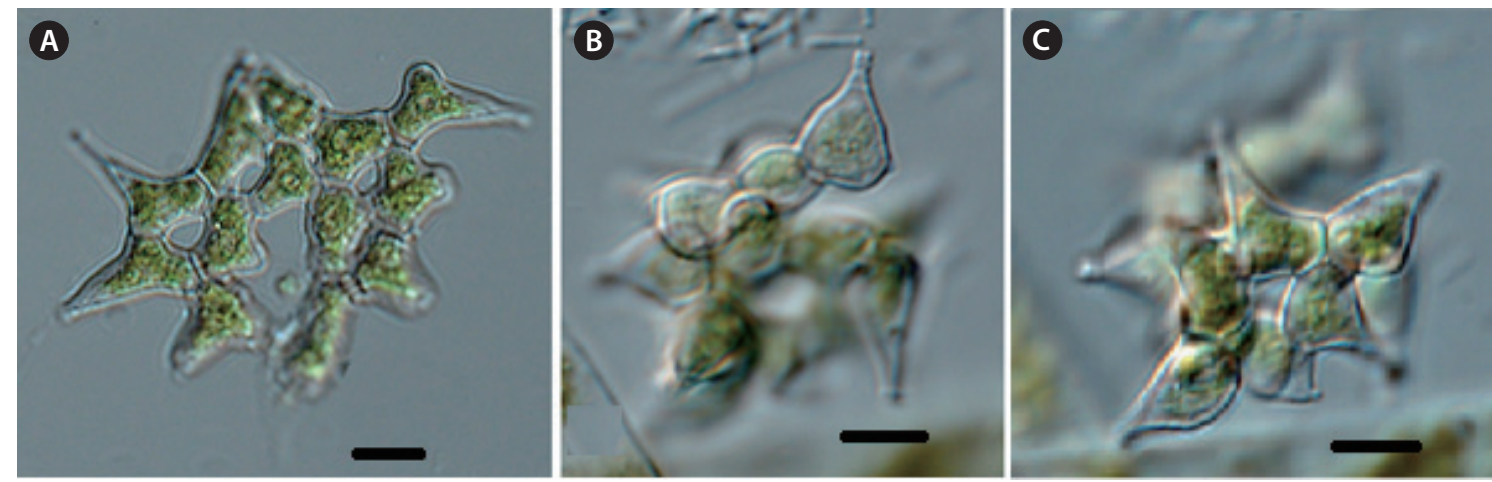

Fig. 3. Pediastrum asymmetricum Hegewald et Yamagishi (A-B: each other colony, B-C: other focusing photographers). Scale bars, $10 \mu \mathrm{m}$. 
marginal cell have 2 small, truncate processes with a lowtriangular base. The inner cells have 5-6 sides, those are nearly straight. The cell wall is granulates. Cells are 15-30 $\mu \mathrm{m}$ in diameter.

\section{Pediastrum obtusum Lucks 1907}

Colonies are subcircular to elliptical. The basal part of the marginal cells is quadrate or obtrapezoid, with two major lobes formed by a deep incision at outer side. The outer sides of each lobe are concave and further divided into two short bluntly rounded lobules. The inner cells have $4-5$, nearly straight sides, with a deep incision on the outer side. The cell wall smooth, Cells are 10-18 $\mu \mathrm{m}$ in diameter.

\section{Pediastrum tetras (Ehrenberg) Ralfs 1844}

Colonies are free-floating, rectangular nearly circular, with 12-74 $\mu \mathrm{m}$ in diameter. The outer sides of the processes are slightly or deeply concave. The inner cells are five to seven angled, with a single deep linear incision and 4-6 straight sides. The marginal cells are 5-18 $\mu \mathrm{m}$ in diameter, and $4-18 \mu \mathrm{m}$ long. The inner cells are $4-16 \mu \mathrm{m}$ in diameter, and $4-14 \mu \mathrm{m}$ long.

\section{Pediastrum privum (Printz) Hegewald 1979 in Hegewald et Schnepf 1979}

Colonies are without perforation, with completely joined cell sides. The marginal cells are straight or slightly concave on the outer sides. Cells are 3-6 $\mu \mathrm{m}$ long, and 4-10 $\mu \mathrm{m}$ in diameter.

\section{Pediastrum boryanum (Turpin) Meneghini 1840}

Colonies are circular to ellipsoid, without perforations, rarely with small perforations. The marginal cells are 6-35 $\mu \mathrm{m}$ long, and 5-31 $\mu \mathrm{m}$ in diameter. The inner cells are 5-26 $\mu \mathrm{m}$ long, and 4-27 $\mu \mathrm{m}$ in diameter.

\section{Pediastrum boryanum var. brevicorne A. Braun 1855} (Fig. 4)

Synonym: Pediastrum boryanum ssp. brevicorne (A. Braun) Raciborski; Pediastrum boryanum var. brevicorne f. glabrum Raciborski; Pediastrum boryanum ssp. brevicorne f. punctatum Raciborski; Pediastrum boryanum f. punctatum Krieger; Pediastrum boryanum var. integriforme Hansgirg; Pediastrum boryanum var. muticum (Kützing) Chodat; Pediastrum muticum Kützing; Pediastrum muticum ssp. brevicorne Raciborski; Pediastrum muticum var. inerme Raciborski; Pediastrum muticum var. inerme f. punctatum Krieger.

Illustration: Colonies are free-floating, circular to ellip- soid, and consisted of 4 to 32 cells, without perforations. The inner cells are tetragonal. The outer sides of the marginal cells have two short processes. Slight incisions are present between both processes, close to the U-shape in the mature cells. The cell wall is granulates. The marginal cells are 10-20 $\mu \mathrm{m}$ long, and 3-20 $\mu \mathrm{m}$ in diameter. The inner cells are 10-20 $\mu \mathrm{m}$ long, and 6-20 $\mu \mathrm{m}$ in diameter.

Information of sampling sites: This species inhabits in lakes, reservoirs and swamps as plankton or benthos, and is collected from the Nakdong river (25 Oct 2011: water temp. 20.0 ${ }^{\circ} \mathrm{C}, \mathrm{pH}$ 8.0, TN $2.044 \mathrm{mg} \mathrm{L}^{-1}$, TP $0.073 \mathrm{mg} \mathrm{L}^{-1}$ ). Swamp in Jangcheok reservoir (15 Aug 2011: water temp. $27.5^{\circ} \mathrm{C}, \mathrm{pH} 8.2$, TN $0.432 \mathrm{mg} \mathrm{L}^{-1}$, TP $0.038 \mathrm{mg} \mathrm{L}^{-1}$ ).

Key reference: Braun (1855).

Remark: This taxon has already been reported in Algal flora of Korea by Kim and Kim (2012).

\section{*Pediastrum boryanum var. campanulatum Wille 1924} (Fig. 5)

Illustration: Colonies are free-floating, circular to ellipsoid with 16-32-64 cells, without perforations. They are campanulate in shape, not flat. Coenobia are 90-150 $\mu \mathrm{m}$ in diameter. The length of the marginal cells is slightly longer than the width. Neighboring cells are in close contact. Processes of the marginal cells have as long as cells, incision deep, and are V-shaped. The inner cells are slightly incised on the outer side. The cell wall is granulates. The marginal cells are 15-25 $\mu \mathrm{m}$ long, and 12-20 $\mu \mathrm{m}$ in diameter. The inner cells are 7-20 $\mu \mathrm{m}$ long, and 7-20 $\mu \mathrm{m}$ in diameter.

Information of sampling sites: This species inhabits in lake and reservoir as plankton, and collected from 88 lake in Olymphic Park (07 Sep 2012: no data of water temp., $\mathrm{pH}$ and EC).

Key reference: Wille (1924).

\section{Pediastrum boryanum var. cornutum (Raciborski) Sulek 1969 (Fig. 6)}

Basionym: Pediastrum duplex var. cornutum Raciborski 1890.

Synonym: Pediastrum cornutum (Raciborski) Traiskaya.

Illustration: Colonies are free-floating, circular to ellipsoid, and consisted of 16-32-64 cells, without perforations, or sometimes with triangular gaps. Colonies are $120-240 \mu \mathrm{m}$ in diameter. The length of the marginal cells is slightly longer than the width, the neighboring cells contact 1/3 the length of cell. Processes of the marginal cells have a small spine. Triangular, intercellular spaces are present between the inner cells. Incisions between 

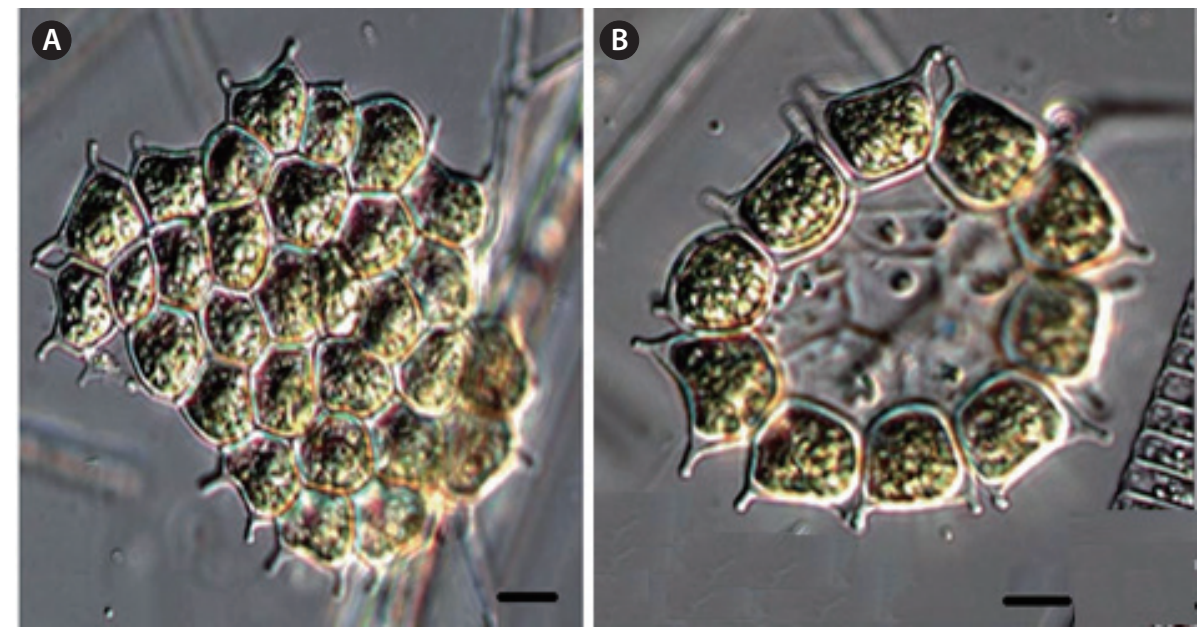

Fig. 4. Pediastrum boryanum var. brevicorne A. Braun (A-B: each other colony). Scale bars, $10 \mu \mathrm{m}$.
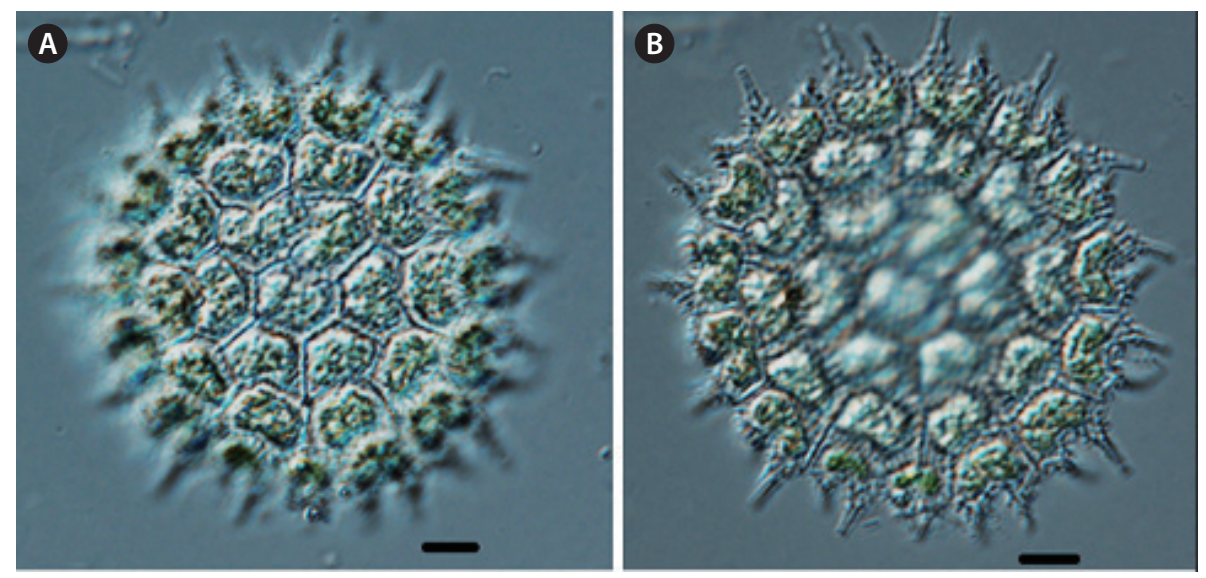

Fig. 5. Pediastrum boryanum var. campanulatum Wille (A-B: other focusing photographers). Scale bars, $10 \mu \mathrm{m}$.
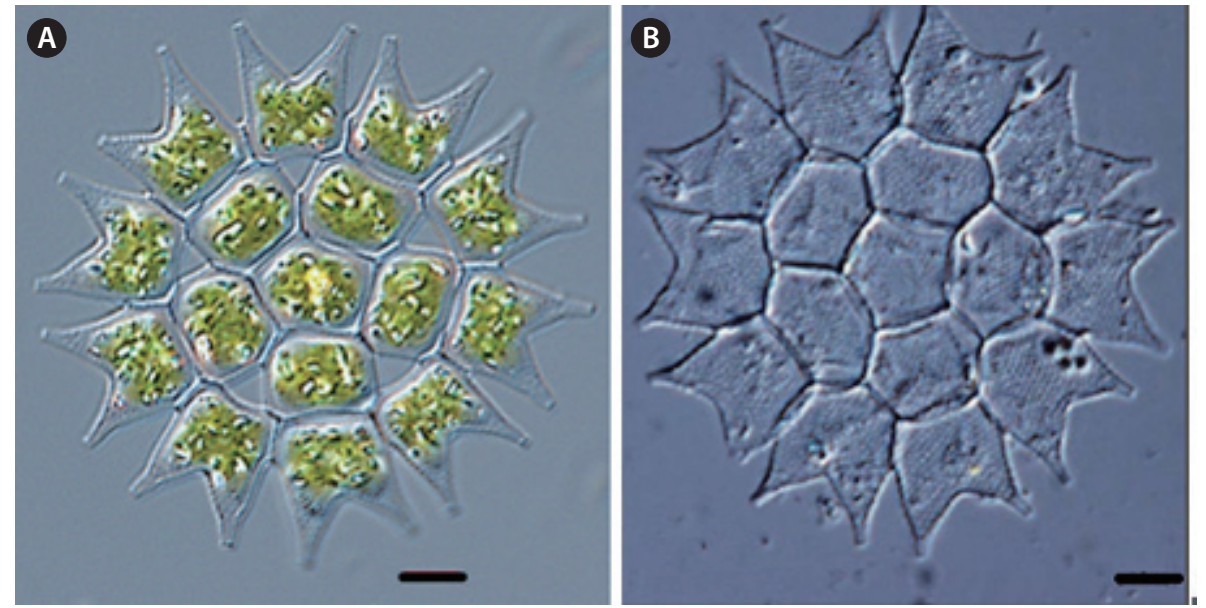

Fig. 6. Pediastrum boryanum var. cornutum (Raciborski) Sulek (A-B: each other colony). Scale bars, $10 \mu \mathrm{m}$. 
both processes are, closed or V-shaped in the mature cells. The cell wall has reticulate sculptures and is granulates. The marginal cells are $15-25 \mu \mathrm{m}$ long, and $12-20 \mu \mathrm{m}$ in diameter. The inner cells are 7-20 $\mu \mathrm{m}$ long, and 7-20 $\mu \mathrm{m}$ in diameter.

Information of sampling sites: This species inhabits in lakes, reservoirs and streams as plankton, and is collected from Lake Geumgang (05 May 2011: water temp. $20.0^{\circ} \mathrm{C}$, pH 8.5, EC $227 \mu \mathrm{cm}^{-1}$,TN $3.536 \mathrm{mg} \mathrm{L}^{-1,}$ TP $0.089 \mathrm{mg} \mathrm{L}^{-1}$ ), Lake Seoho (03 Sep 2011: water temp. $24.1^{\circ} \mathrm{C}$, pH 7.3, EC $569 \mathrm{us} \mathrm{cm}^{-1}$, TN $6.515 \mathrm{mg} \mathrm{L}^{-1}$, TP $0.278 \mathrm{mg} \mathrm{L}^{-1}$ ), Lake Pomun (10 Sep 2011: water temp. $20.3^{\circ} \mathrm{C}$, pH 8.4, EC $82 \mu \mathrm{s} \mathrm{cm}^{-1}$,TN $0.479 \mathrm{mg} \mathrm{L}^{-1}$, TP $0.016 \mathrm{mg} \mathrm{L}^{-1}$ ), Pond at KAIST (10 Sep 2011: no data), Donghwa stream (16 Sep 2011: water temp. 22.9 ${ }^{\circ} \mathrm{C}$; pH 7.6; TN $7.277 \mathrm{mg} \mathrm{L}^{-1 ;} \mathrm{TP} 0.050 \mathrm{mg} \mathrm{L}^{-1}$ ), Ugeum Reservoir (31 Oct 2011; water temp. $10.7^{\circ} \mathrm{C}, \mathrm{pH} 8.7$, , EC 95 $\mu \mathrm{cm}^{-1}$, TN $1.103 \mathrm{mg} \mathrm{L}^{-1}$, TP $0.055 \mathrm{mg} \mathrm{L}^{-1}$ ), Ilwang Reservoir (31 Oct 2011: no data).

Key reference: Sulek (1969).

Remark: This taxon is already reported in Algal flora of Korea by Kim and Kim (2012).

\section{Pediastrum boryanum var. longicorne Reinsch 1867}

Colonies are circular to ellipsoid. The marginal cells have outer margins that extended into longer processes than are noted in the typical species and the apices of the long processes swollen roundly. The inner cells consisted of 5-6 sides, with or without small intercellular spaces. The marginal cells are 9-40 $\mu \mathrm{m}$ long, and 6-30 $\mu \mathrm{m}$ in diameter. The inner cells are 5-25 $\mu \mathrm{m}$ long, and 6-28 $\mu \mathrm{m}$ in diameter.

\section{Pediastrum boryanum var. forcipatum (Corda) Chodat 1902 (Fig. 7) \\ Basionym: Euastrum forcipatum Corda 1839. \\ Synonym: Pediastrum boryanum ssp. forcipatum (Cor-} da) Raciborski; Pediastrum boryanum var. forcipatum $\mathrm{f}$. setigera Morozova-Vodjanickaja; Pediastrum forcipatum (Corda) A. Braun.

Illustration: Colonies are free-floating, circular to ellipsoid, and consisted of 8 to 64 cells, sometimes 64-128 cells, without perforations. The outer sides of the marginal cells have two long horn-like processes, which gather a point. Incisions were present between both processes, which are V-shaped and deep. The inner cells slightly incised on the outer side. The cell wall is reticulate with dense granulates. The marginal cells are 13-27 $\mu \mathrm{m}$ long, and $14-23 \mu \mathrm{m}$ in diameter. The inner cells are $14-22 \mu \mathrm{m}$ long, and $12-22 \mu \mathrm{m}$ in diameter.

Information of sampling sites: This species inhabits in ponds, lakes and reservoirs as plankton, and is collected from Lake Geumgang (05 May 2011: water temp. $20.0^{\circ} \mathrm{C}$, pH 8.5, EC $227 \mu \mathrm{cm}^{-1}$,TN $3.536 \mathrm{mg} \mathrm{L}^{-1,}$ TP $0.089 \mathrm{mg} \mathrm{L}^{-1}$, Lake Seoho (03 Sep2011: water temp. $24.1^{\circ} \mathrm{C}$, pH 7.3, EC $569 \mathrm{ss} \mathrm{cm}^{-1}$, TN $6.515 \mathrm{mg} \mathrm{L}^{-1}$, TP $0.278 \mathrm{mg} \mathrm{L}^{-1}$ ), Lake Pomun (10 Sep 2011: water temp. 20.3 ${ }^{\circ} \mathrm{C}$, pH 8.4, EC $82 \mu \mathrm{cm}^{-1}$,TN $0.479 \mathrm{mg} \mathrm{L}^{-1,} \mathrm{TP} 0.016 \mathrm{mg} \mathrm{L}^{-1}$ ), Pond at KAIST (10 Sep 2011: no data).

Key reference: Chodat (1902).

Remark: This taxon has already been reported in Algal flora of Korea by Kim and Kim (2012).

\section{Pediastrum boryanum var. pseudoglabrum Parra 1979} (Fig. 8)

Illustration: Colonies are free-floating, circular to ellipsoid, and consisted of 4-32 cells, with perforations. The outer sides of the marginal cells have two short, horn-like processes. There are slight incisions between both processes, which were wide, shallow, and U-shaped in mature cells. The cell wall has a pore-like structure, and is granulates. The marginal cells are 8-14 $\mu \mathrm{m}$ long, 8-11 $\mu \mathrm{m}$ in diameter. The inner cells are $8-10 \mu \mathrm{m}$ long, $8-11 \mu \mathrm{m}$ in diameter.

Information of collected sites: This species inhabits in ponds, lakes and reservoirs as plankton, and is collected from Lake Geumgang (05 May 2011: water temp. $20.0^{\circ} \mathrm{C}$, pH 8.5, EC $227 \mu \mathrm{cm}^{-1}$,TN $3.536 \mathrm{mg} \mathrm{L}^{-1}$ TP $0.089 \mathrm{mg} \mathrm{L}^{-1}$ ), Lake Seoho (03 Sep 2011: water temp. $24.1^{\circ} \mathrm{C}$, pH 7.3, EC $569 \mathrm{\mu s} \mathrm{cm}^{-1}$, TN $6.515 \mathrm{mg} \mathrm{L}^{-1}$, TP $0.278 \mathrm{mg} \mathrm{L}^{-1}$ ), Lake Pomun (10 Sep 2011: water temp. $20.3^{\circ} \mathrm{C}$, pH 8.4, EC $82 \mu \mathrm{cm}^{-1}$,TN $0.479 \mathrm{mg} \mathrm{L}^{-1,}$ TP $0.016 \mathrm{mg} \mathrm{L}^{-1}$ ), Pond at KAIST (10 Sep 2011: no data).

Key reference: Parra (1979).

Remark: This taxon has already been reported in Algal flora of Korea by Kim and Kim (2012).

\section{Pediastrum boryanum var. perforatum (Raciborski) Ni-} tardy 1914

Colonies are circular to ellipsoid, with perforations. The outer sides of the marginal cells have two short hornlike processes, which tapered gradually. The cell walls are reticulate sculptures, with granulates. The marginal cells are 10-26 $\mu \mathrm{m}$ long, 8-20 $\mu \mathrm{m}$ in diameter. The inner cells are 6-22 $\mu \mathrm{m}$ long, 8-20 $\mu \mathrm{m}$ in diameter.

\section{Pediastrum angulosum (Ehrenberg) Meneghini 1840}

Colonies are circular to ellipsoid, without perforations. The outer sides of the marginal cells have two low and horn-like processes. The incised apex of the processes formed a V-shape. The inner cells are tetragon. The cell 
wall has reticulate ridges. The marginal cells are 10-24 $\mu \mathrm{m}$ long, and 8-22 $\mu \mathrm{m}$ in diameter. The inner cells are 8-18 $\mu \mathrm{m}$ long, and 8-18 $\mu \mathrm{m}$ in diameter.

Pediastrum angulosum var. asperum Sulek in Komarek et Fott 1983 (Fig. 9)

Synonym: Pediastrum duplex var. coronatum Raciborski.

Illustration: Colonies are free floating, circular, or ellipsoidal, and consisted of 16, 32, 64 and 128 cells, with-
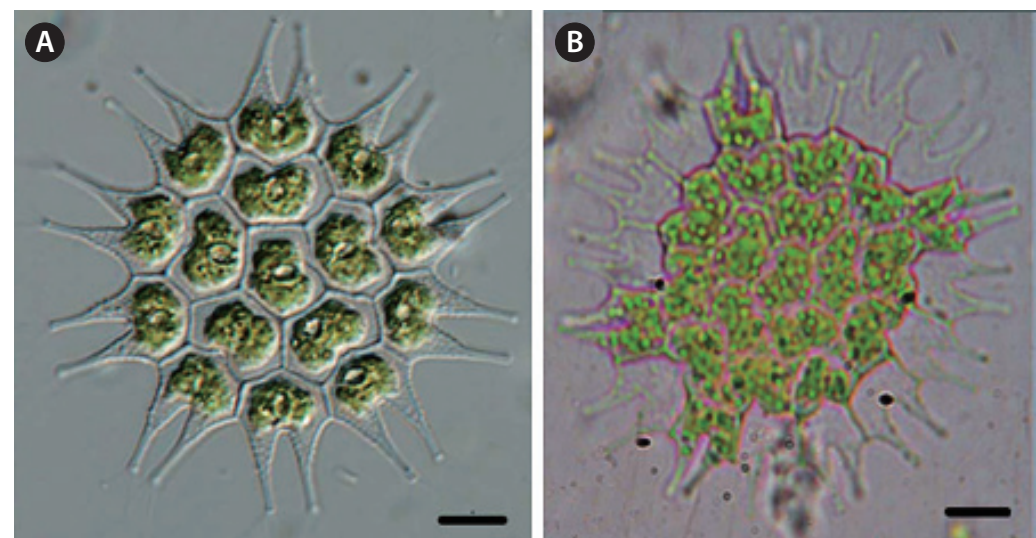

Fig. 7. Pediastrum boryanum var. forcipatum (Corda) Chodat (A-B: each other colony). Scale bars, $10 \mu \mathrm{m}$.
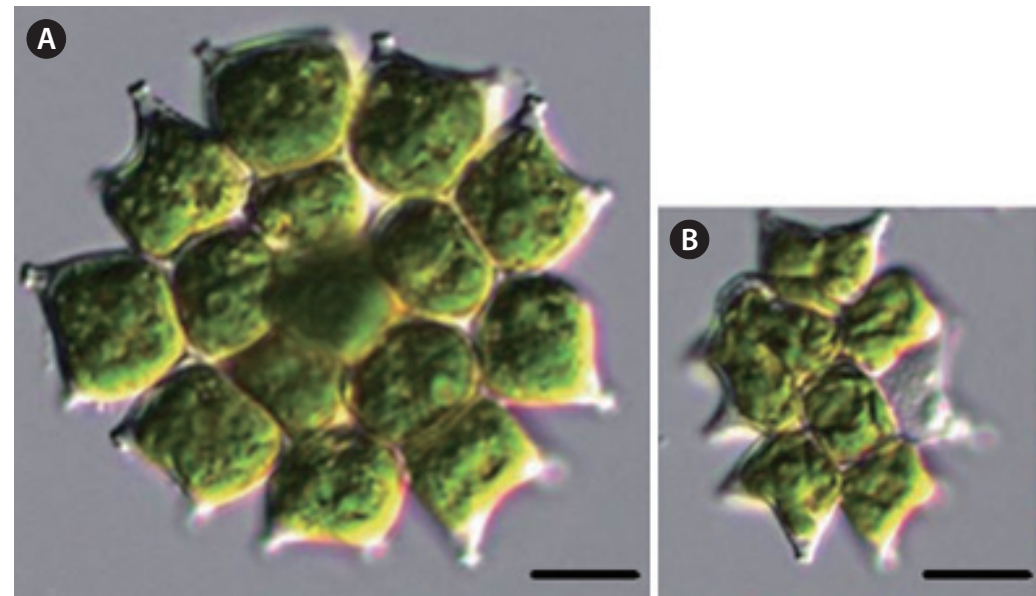

Fig. 8. Pediastrum boryanum var. pseudoglabrum Parra (A-B: each other colony). Scale bars, $10 \mu \mathrm{m}$.

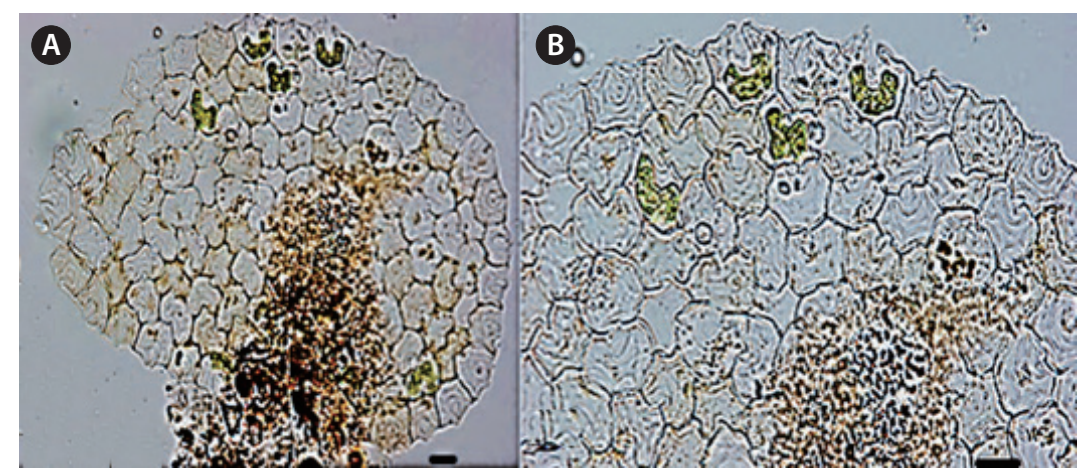

Fig. 9. Pediastrum angulosum var. asperum Sulek in Komarek et Fott (A: $\times 320, B: \times 640)$. Scale bars, $10 \mu \mathrm{m}$. 


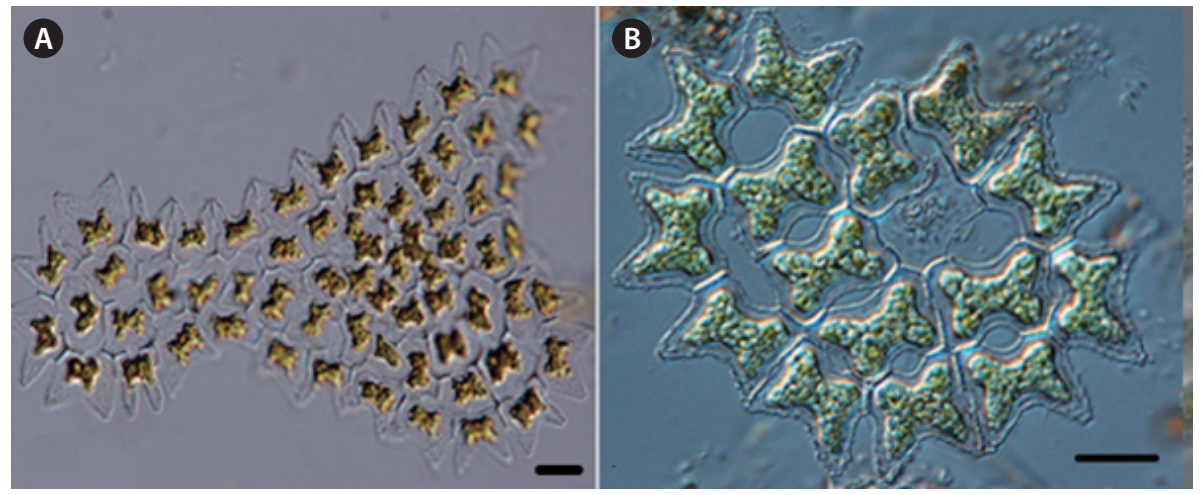

Fig. 10. Pediastrum argentiniense Bourrelly et Tell in Tell (A-B: each other colony). Scale bars, $10 \mu \mathrm{m}$.
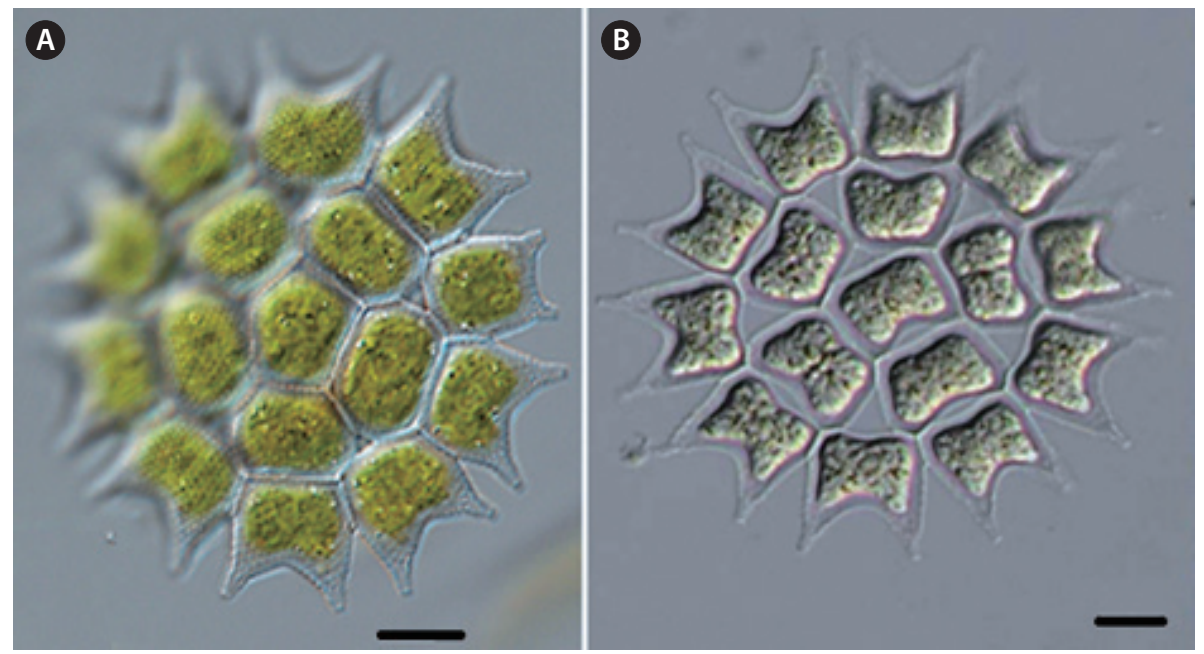

Fig. 11. Pediastrum subgranulatum (Raciborski) Komarek et Jankovska (A-B: each other colony). Scale bars, $10 \mu \mathrm{m}$.

out perforation. The basal portion of the marginal cells is polygonal, often quadrate, or pentagonal. Both apices of the outer side are slightly concave, with a V- or U-shaped incision, with two conical processes. The inner cells are polygonal, often pentagonal or hexagonal. The cell wall has irregularly reticulate ridges. Cells are 10-12 $\mu \mathrm{m}$ long, and $10-12 \mu \mathrm{m}$ in diameter.

Information of sampling sites: This species inhabits in swamp as benthos, and is collected from Dongbaek dongsan, Jeju (05 Apr 2013: water temp. $22.7^{\circ} \mathrm{C}$, pH 6.0, EC 83 $\left.\mu \mathrm{s} \mathrm{cm}^{-1}\right)$.

Key reference: Sulek (1969).

Remark: This taxon has already been reported in Algal flora of Korea by Kim and Kim (2012).

\section{Pediastrum argentiniense Bourrelly et Tell in Tell 1979} (Fig.10)
Illustration: Colonies are free floating, circular to ovoid, or slightly irregular, consisted of 16 to 64 or more cells, and have small lenticular perforations between the cells. The basal part of the marginal cells is quadrate or curved quadrate, with two triangular processes formed by a broad V-shaped depression at the outer sides. The lateral sides of neighboring cells are almost joined together, except for a lenticular pore, but sometimes separated by a narrow U- or V-shaped interstice. The inner cells are nearly broad, $\mathrm{H}$-shaped with a perforation between the joining. The cell wall is densely granulates. Cells are 12-20 $\mu \mathrm{m}$ long, and 9-24 $\mu \mathrm{m}$ in diameter.

Information of Collected sites: This species inhabits in lakes and reservoirs as plankton, and collected from Dongbaekdongsan, Jeju (05 Apr 2013: water temp. $22.7^{\circ} \mathrm{C}$, pH 6.0, EC $\left.83 \mu \mathrm{sm}^{-1}\right)$.

Key reference: Tell (1979). 
Remark: This taxon has already been reported in Algal flora of Korea by Kim and Kim (2012).

\section{Pediastrum biradiatum Meyen 1829}

Colonies are subcircular, with large perforations. The marginal cells are curved quadrate, and the inner cells are $\mathrm{H}$-shaped. The cell wall is smooth. The marginal cells are 9-26 $\mu \mathrm{m}$ long, and 8-24 $\mu \mathrm{m}$ in diameter, the inner cells are 8-22 $\mu \mathrm{m}$ long, and 9-24 $\mu \mathrm{m}$ in diameter.

\section{Pediastrum duplex Meyen 1829}

Colonies are flat, circular to oval plated, ellipsoidal, and one cell thick. The marginal cells are similar or have two horn-like processes. The inner cells are typically polyhedral with four to many sides. The marginal cells are 7-24 $\mu \mathrm{m}$ long, and 6-22 $\mu \mathrm{m}$ in diameter. The inner cells 5-24 $\mu \mathrm{m}$ long, and 5-27 $\mu \mathrm{m}$ in diameter.

\section{Pediastrum duplex var. gracillimum West et G.S. West 1895}

Colonies are flat, circular to oval plated, ellipsoidal. The marginal cells are similar or have two horn-like processes. The inner cells are typically polyhedral with four to many sides. The marginal cells are 7-24 $\mu \mathrm{m}$ long, and 6-22 $\mu \mathrm{m}$ in diameter. The inner cells 5-24 $\mu \mathrm{m}$ long, and 5-27 $\mu \mathrm{m}$ in diameter.

\section{Pediastrum duplex var. rugulosum Raciborski 1890}

Colonies are circular to oval plated, ellipsoidal, 15-180 $\mu \mathrm{m}$ in diameter. The marginal cells are similar or have two horn-like processes, which tapered gradually. The marginal and inner cells are deeply concave or slightly incised on the outer sides. The cell walls are smooth, finely reticulate, or highly granulate. The marginal cells are 9-18 $\mu \mathrm{m}$ long, and 10-18 $\mu \mathrm{m}$ in diameter. The inner cells are 8-18 $\mu \mathrm{m}$ long, and 8-18 $\mu \mathrm{m}$ in diameter.

\section{Pediastrum duplex var. asperum (A. Braun) Hansgirg 1886}

Colonies are flat, circular to oval plated, ellipsoidal, and one cell thick. The marginal cells are similar or have two horn-like processes, which tapered gradually. The inner side of the marginal cells is concave, the outer side is deeply concave and always wide (V-shaped). The cell wall is irregular. The marginal cells are 8-22 $\mu \mathrm{m}$ long, and 8-19 $\mu \mathrm{m}$ in diameter. The inner cells are 8-18 $\mu \mathrm{m}$ long, and 8-19 $\mu \mathrm{m}$ in diameter.

Pediastrum subgranulatum (Raciborski) Komarek et Jankovska 2001 (Fig. 11)
Synonym: Pediastrum duplex var. subgranulatum Raciborski.

Illustration: Colonies are free floating, flat, circular to oval plated, ellipsoidal, and one cell thick. Colonies typically have 16-64 cells, $100-160 \mu \mathrm{m}$ in diameter, and have small lens-shaped perforation between the cells, The length of the marginal cells is quadrate, slightly longer than wide, with short two horn-like processes, which tapered gradually. The inner side of the marginal cells is concave. The outer side is deeply concave and always wide (rounded V-shape). The inner cells are quadrate to angular and widely concave in the central margin, and in contact at the central portion of the side wall. The cell wall is fine and densely granulates. The marginal cells are 8-23 $\mu \mathrm{m}$ long, 8-19 $\mu \mathrm{m}$ in diameter. The inner cells 8-14 $\mu \mathrm{m}$ long, 8-23 $\mu \mathrm{m}$ in diameter.

Information of sampling sites: This species inhabits in streams and lakes as plankton, and is collected from the Dongchang stream in Cheongdo-gun (Imdang bridge) (13 May 2009: no data).

Key reference: Komarek and Jankovska (2001).

Remark: This taxon has already been reported in Algal flora of Korea by Kim and Kim (2012).

\section{Genus Sorastrum Kützing 1845}

\section{Sorastrum americanum (Bohlin) Schmidle 1900}

Colonies are spherical. The cells are reniform to cuneate, three angled, and radiately arranged at the center to a gelatinous sphere by a short stalk from the basal angle of the cell. Cells are 7-20 $\mu \mathrm{m}$ wide, 10-18 $\mu \mathrm{m}$ long and 4-8 $\mu \mathrm{m}$ thick.

\section{Sorastrum spinulosum Nägeli 1849}

Colonies are spherical. The cells are rhomboidal, reniform, cuneate, three sided and radiately united at the center to a gelatinous sphere by a short stalk from the basal side. The outer side of cells have two short, 1-4 stout outwardly directed spines. The cells are 8-20 $\mu \mathrm{m}$ wide, 6-18 $\mu \mathrm{m}$ long, and 5-8 $\mu \mathrm{m}$ thick. The spines are 4-5 $\mu \mathrm{m}$ long.

\section{Family Coelastraceae Wille}

\section{Genus Coelastrum Nägeli 1849}

\section{Coelastrum microporum Nägeli in A. Braun 1855}

Colonies are spherical. The cells are also spherical, sometimes ovoid, without any processes on the outer side or interconnecting processes. The cells are 8-20 $\mu \mathrm{m}$ in diameter. 
${ }^{*}$ Coelastrum microporum var. octaedricum (Skuja) Sodomkova 1972 (Fig. 12)

Basionym : Coelastrum octaedricum Skuja 1948.

Illustration: Colonies are tetrahedral, consisted of 4-8cells. The cells are spherical, sometimes ovoid, and enclosed to adjacent surrounding cells with very small connecting processes. Cells are 8-17 $\mu \mathrm{m}$ in diameter.

Information of sampling sites: This species inhabits in lakes and reservoirs as plankton and on wet soil as benthos, and is collected from fishery of Giljeong (30 May 2012: water temp. $24.0^{\circ} \mathrm{C}, \mathrm{pH} 8.8$, EC $186 \mu \mathrm{sm}^{-1}$, TN 0.948 $\mathrm{mg} \mathrm{L}^{-1}$, TP $0.019 \mathrm{mg} \mathrm{L}^{-1}$ ), Seorang reservoir (30 May 2012: water temp. $30.4^{\circ} \mathrm{C}, \mathrm{pH} 7.0$, EC $294.6 \mu \mathrm{s} \mathrm{cm}{ }^{-1}$ ), Sayanggol reservoir (29 Apr 2012: water temp. $18.2^{\circ} \mathrm{C}$, pH 9.2, EC $162.8 \mathrm{us} \mathrm{cm}^{-1}$ ), Spring at Tennis court of Daejin University (26 Sep 2012: no data), Lake Seoho (20 Nov 2012: water temp. $9.4^{\circ} \mathrm{C}, \mathrm{pH} 7.6$, EC $447 \mu \mathrm{sm}^{-1}, \mathrm{TN} 2.720 \mathrm{mg} \mathrm{L}^{-1,} \mathrm{TP}$ $0.086 \mathrm{mg} \mathrm{L}^{-1}$ ), Oknyeo reservoir (22 Sep 2012: water temp. $24^{\circ} \mathrm{C}$, pH 9.0, EC $572 \mu \mathrm{sm}^{-1}$, TN $0.855 \mathrm{mg} \mathrm{L}^{-1}$, TP $0.194 \mathrm{mg}$ $\mathrm{L}^{-1}$ ), Euirim reservoir (31 Aug 2012: water temp. $28.2^{\circ} \mathrm{C}, \mathrm{pH}$ 7.5, EC $138 \mu \mathrm{s} \mathrm{cm}^{-1}$ ).

Key reference: Sodomková (1972).

\section{Coelastrum astroideum De-Notaris 1867}

Colonies are spherical. The cells are spherical, sometimes ovoid, without obvious interconnecting processes. Cells are $8-20 \mu \mathrm{m}$ in diameter.

\section{Coelastrum cambricum Archer 1868}

Colonies are spherical. The cells are spherical, enclosed by a gelatinous sheath, and have a single process protrude toward the outer free side, which is interconnected and adjoined to cells by the marginal processes. Cells are 6-20 $\mu \mathrm{m}$ in diameter.

\section{Coelastrum sphaericum Nägeli 1849}

Colonies are spherical or ovoid. The cells are ovoid or conical, connected to other cells by short processes. Cells are $6-25 \mu \mathrm{m}$ in diameter.

\section{Coelastrum proboscideum Bohlin 1897}

Colonies are pyramidal. The cells are conical, truncate or hexagonal, connected to adjacent cells by short, stout processes. Cells are 8-15 $\mu \mathrm{m}$ in diameter.

\section{*Coelastrum morus W. et G.S. West 1896 (Fig. 13)}

Illustration: Colonies are spherical or ovoid, and consisted of 4, 8, 16 or 32 cells. The cells are spherical, and have truncate wart-like processe toward the outer free side. The cells are interconnected to adjacent cells at the base of cell by short, stout gelatinous processes, Cells are $6-10 \mu \mathrm{m}$ in diameter.

Information of collected sites: This species inhabits in ponds, lakes and reservoirs as plankton or on west soil as benthos, and is collected from wet soil and spring at Tennis court in Daejin University (26 Sep 2012: no data), Pond at KAIST (11 Sep 2011: no data).

Key reference: West and West (1896).

\section{*Coelastrum pulchrum Schmidle 1892 (Fig. 14)}

Synonym: Coelastrum cambricum W. Archer sensu auct. Post;

Coelastrum shensiense Jao.

Illustration: Colonies are spherical, consisting 8-16 or 32 cells. The cells spherical, and ovoid, and have a single stout, rounded truncate process projected toward the outside. The cell is connected to an adjacent cell by 4-6 short, stout processes. Intercellular spaces are spherical or triangular, Chloroplast is parietal, with a pyrenoid. Cells are 10-15 $\mu \mathrm{m}$ in diameter.

Information of sampling sites: This species inhabits in lake and reservoir as plankton, and is collected from Lake 88 in Olymphic Park (07 Sep 2012: no data).

Key reference: Schmidle (1893).

\section{*Coelastrum indicum Turner 1892 (Fig. 15)}

Synonym: Coelastrum pulchrum var. intermedium Bohlin; Coleastrum intermedium (Bohlin) Korshikov.

Illustration: Colonies are spherical, and consisted of 8 , 16,32 or 64 cells. The cells are spherical or ovoid, with 5-6 sides in view of the apex. The cell wall of the outer face is slightly thickened. The cells are interconnected to adjacent cells by the processes of the 5-6 lateral at basal part. Intercellular spaces are small, triangular. Chloroplast is parietal, with a pyrenoid, Cells are 5-18 $\mu \mathrm{m}$ in diameter.

Information of sampling sites: This species inhabits in lakes and reservoirs as plankton, and is collected from Imcheon reservoir (09 Jun 2012: water temp. $27.2^{\circ} \mathrm{C}, \mathrm{pH}$ 6.5, EC $129.7 \mu \mathrm{cm}^{-1}, \mathrm{TN} 0.995 \mathrm{mg} \mathrm{L}^{-1,} \mathrm{TP} 0.044 \mathrm{mg} \mathrm{L}^{-1}$ ), Seorang reservoir (27 May 2012: water temp. $30.4^{\circ} \mathrm{C}, \mathrm{pH}$ 7.0, EC $294.6 \mu \mathrm{sm}^{-1}$ ), Lake 88 at Olymphic Park (26 Aug 2012: no data), Wangsong reservoir (27 May 2012: water temp. $29.5^{\circ} \mathrm{C}$, pH 7.8, EC $435 \mu \mathrm{cm}^{-1}$, TN $3.255 \mathrm{mg} \mathrm{L}^{-1,} \mathrm{TP}$ $0.136 \mathrm{mg} \mathrm{L}^{-1}$ ).

Key reference: Turner (1892).

\section{Coelastrum reticulatum (Dangeard) Senn 1899}

Colonies are spherical. The cells are also spherical, without wart-like truncate processes, and interconnected to adjacent cells by 1-3 long and slender finger-like 

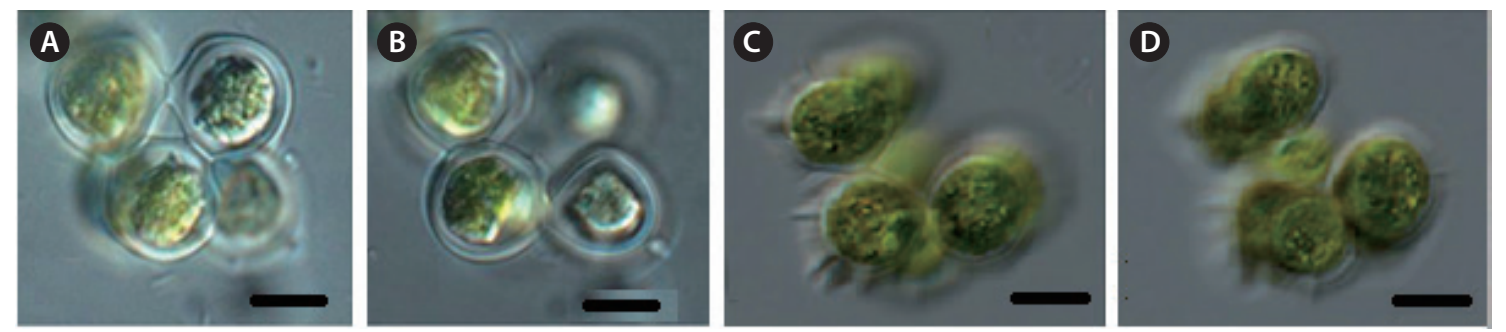

Fig. 12. Coelastrum microporum var. octaedricum (Skuja) Sodomkova (A-B and C-D: other colonies and focusing photographers). Scale bars, $10 \mu m$.
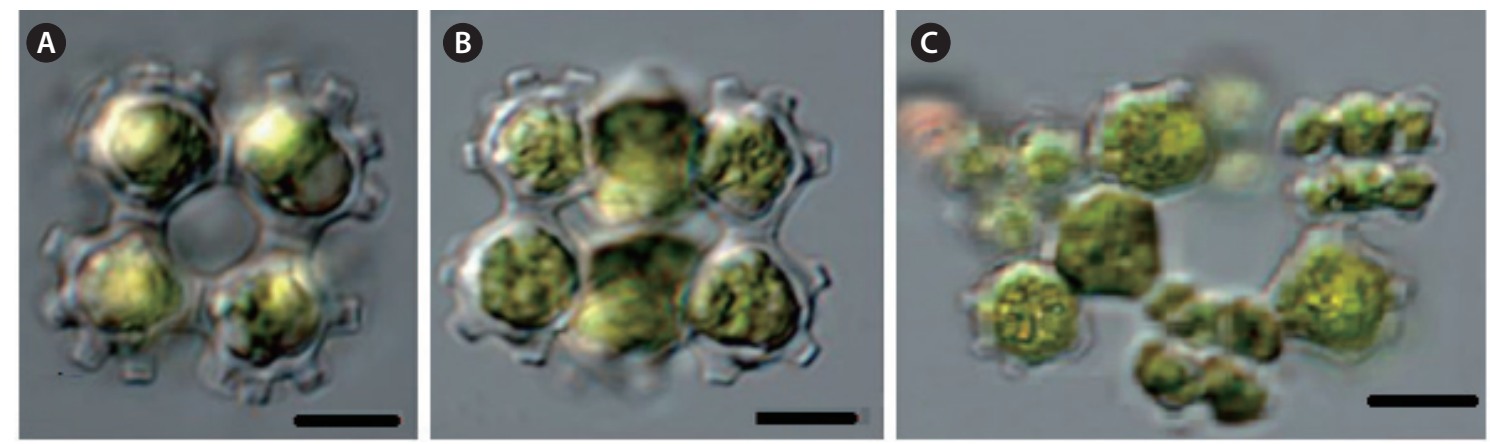

Fig. 13. Coelastrum morus West et G.S. West (A-C: each other individual, C: mature cells and daughter cells) Scale bars, $10 \mu \mathrm{m}$.
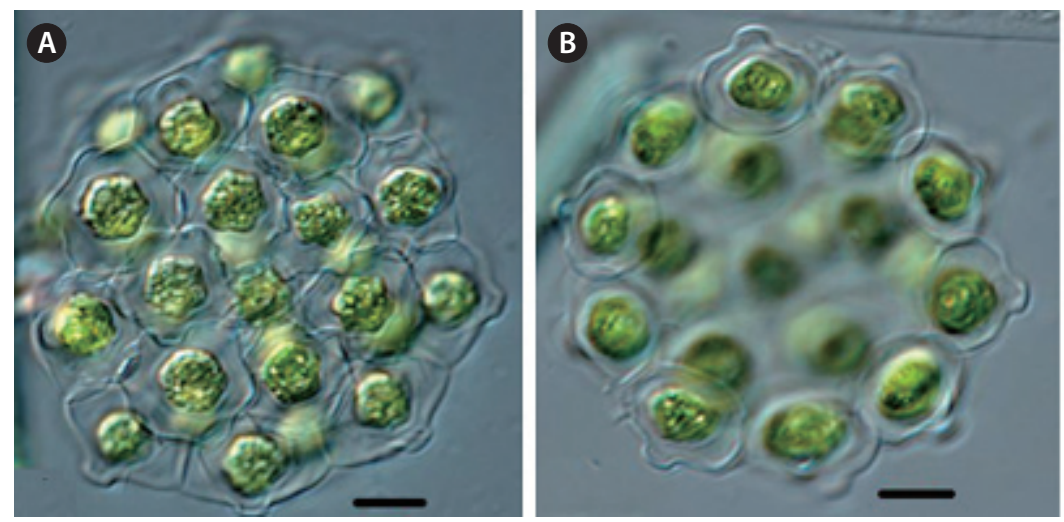

Fig. 14. Coelastrum pulchrum Schmidle (A-B: other focusing photographers). Scale bars, $10 \mu \mathrm{m}$.

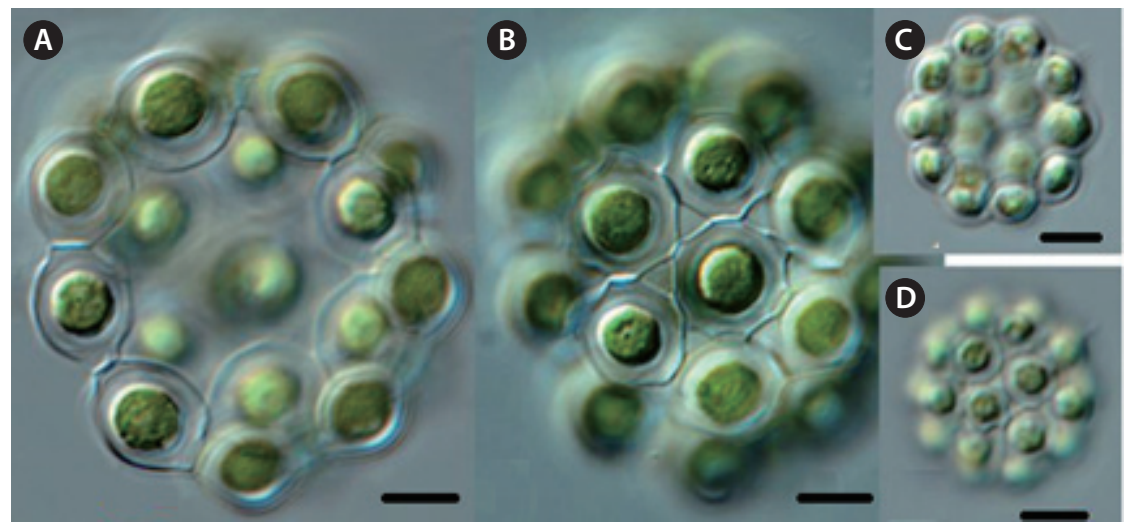

Fig. 15. Coelastrum indicum Turner (A-B, C-D: other individuals and focusing photographers, C-D: immature colonies). Scale bars, $10 \mu \mathrm{m}$. 
processes. Cells are 6-15 $\mu \mathrm{m}$ in diameter.

\section{Coelastrum polychordum (Korshikov) Hindak 1977}

Colonies are spherical. The cells are spherical, have truncate wart-like processes, and are interconnected to adjacent cells by 1-3 long and slender finger-like processes. Cells are 6-15 $\mu \mathrm{m}$ in diameter.

\section{Genus Actinastrum Lagerheim 1882}

\section{Actinastrun hantzschii Lagerheim 1882}

Cells radiatyely arranged from the center of colonies, cells cylindrical fusiform but truncate at the poles. Cells are 10-26 $\mu \mathrm{m}$ in diameter, and 3-6 $\mu \mathrm{m}$ in diameter.

\section{*Actinastrum hantzschii var. subtile Woloszynska 1911} (Fig. 16)

Synonym : Actinastrum hantzschii var. gracile Roll; Actinastrum hantzschii var. fluviatile Schröder sensu Prescott und Komarek.

Illustration: Colonies are free floating, and consisted of 4,8 , or 16 cells. The cells are radially arranged from the center of the colony. The cells are cylindrical fusiform, the outer pole is pointed, and the inner pole is truncate, a single chloroplast is parietal, with a single pyrenoid, Cells are 10-30 $\mu \mathrm{m}$ long, and 2-3 $\mu \mathrm{m}$ in diameter.

Information of sampling sites: This species inhabits in lakes, reservoirs and river as plankton, and is collected from Bunhwangri reservoir (10 Nov 2012: water temp. $33.8^{\circ} \mathrm{C}, \mathrm{pH} 6.5$, EC $229 \mu \mathrm{sm}^{-1}$ ), the Estuary of Mankyeong river (19 Sep 2012: water temp. $23.5^{\circ} \mathrm{C}$, pH 8.5, EC 1880 $\mu \mathrm{cm}^{-1}$, TN $2.287 \mathrm{mg} \mathrm{L}^{-1}$, TP $\left.0.127 \mathrm{mg} \mathrm{L}^{-1}\right)$, the Estuary of Dongjin river (19 Sep 2012: water temp. $23.0^{\circ} \mathrm{C}$, pH 7.0, EC $806 \mu \mathrm{cm}^{-1}$,TN $2.072 \mathrm{mg} \mathrm{L}^{-1,}$ TP $0.048 \mathrm{mg} \mathrm{L}^{-1}$ ), Lake Seoho (20 Nov 2012: no data), Lake 88 at Olymphic Park (07 Sep 2012: no data).

Key reference: Woloszynska (1911).

\section{Actinastrum fluviatile (Schröder) Fott 1977}

Cells are radiately arranged from the center of the colony, cells are cylindrical fusiform. Cells are 10-20 $\mu \mathrm{m}$ long, and $5 \mu \mathrm{m}$ in diameter.

\section{*Actinastrum aciculare Playfair 1917 (Fig. 17)}

Illustration: Colonies are free floating, and consisted of 4,8 or 16 cells. The cells are radially arranged from the center of colony and are composed of coenobium. The cells are curved, slender, long cylindrical fusiform. The outer pole is sharply pointed, and the inner pole is truncate. a single chloroplast is parietal, with a pyrenoid. Cells are 10-30 $\mu \mathrm{m}$ long, and 2-3 $\mu \mathrm{m}$ in diameter.

Information of sampling sites: This species inhabits in lakes, reservoirs and river as plankton, and is collected from the Estuary of Mankyeong river (19 Sep 2012: water temp. $23.5^{\circ} \mathrm{C}$, pH 8.5, EC $1880 \mu \mathrm{cm}^{-1}$, TN $2.287 \mathrm{mg} \mathrm{L}^{-1,} \mathrm{TP}$ $0.127 \mathrm{mg} \mathrm{L}^{-1}$ ), the Estuary of Dongjin river (19 Sep 2012: water temp. $23.0^{\circ} \mathrm{C}, \mathrm{pH} 7.0$, EC $806 \mu \mathrm{sm}^{-1}$, TN $2.072 \mathrm{mg}$ $\mathrm{L}^{-1,}$ TP $\left.0.048 \mathrm{mg} \mathrm{L}^{-1}\right)$.

Key reference: Playfair (1917).

\section{Actinastrum gracillimum Smith 1916}

Cells are radiately arranged from the center of the colony, and rounded truncate at the both poles. Cells are 10$15 \mu \mathrm{m}$ long, and 2-3 $\mu \mathrm{m}$ in diameter.

\section{Actinastrum gracillimum var. elongatum (Smith) Fott 1977}

Cells are radially arranged from the center of the colony and are composed of coenobium. Cells are 30-45 $\mu \mathrm{m}$ long, and 3-5 $\mu \mathrm{m}$ in diameter.

Taxa belonging to these two families (Hydrodictyaceae, Coelastraceae) are distributed cosmopolitan areas (Komarek and Fott 1983, Komarek and Jankovska 2001, Prescott 1962, Yamagishi and Akiyama 1984-1997, Parra 1979). They inhabit standing waters (e.g., swamps, fish ponds, ponds, reservoirs, lakes) and running waters (e.g., rivers, streams) in Korea (1968, Chung et al. 1972, Chung and Lee 1978, Kang 1967, Kim 1994, 1996, Kim and Chang 1997, Kim and Chung 1993, Kim and Lee 1995, Yang et al. 1981).

The surface sculptures of the genus Pediastrum depend on the environmental conditions and developmental stage to its age but the type is stable and speciesspecific (Komarek and Janovska 2001). Different taxa have characteristics of various cell wall types. Parra (1979) reported that it is difficult to identify species by the external characteristics of their cells and coenobium. Classification based on their ultrastructure for more exact species identification is necessary. However, many researchers have classified species based on the perforation between the cells, shape of the marginal cells and ornamentations (sculptures or granulates) on the cell wall by light microscopy.

Several species (i.e., P. boryanum, P. duplex, P. simplex and $P$. tetras) are distributed worldwide. P. simplex is commonly distributed in tropical and temperate areas. Three taxa have a broad ecological tolerance (Komarek and Jankovska 2001).

The genus Pediastrum is reported to be comprised of 12 species, 15 varieties, 3 forma (i.e., $P$ angulosum, $P$. $b i$ - 

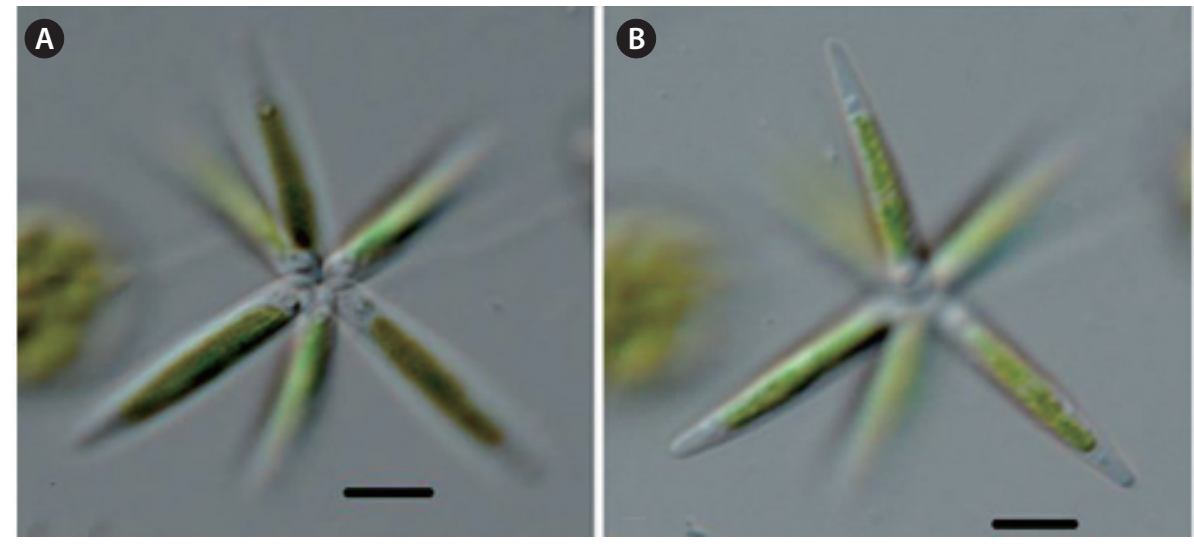

Fig. 16. Actinastrum hantzschii var. subtile Woloszynska (A-B: other focusing photographers). Scale bars, $10 \mu \mathrm{m}$.
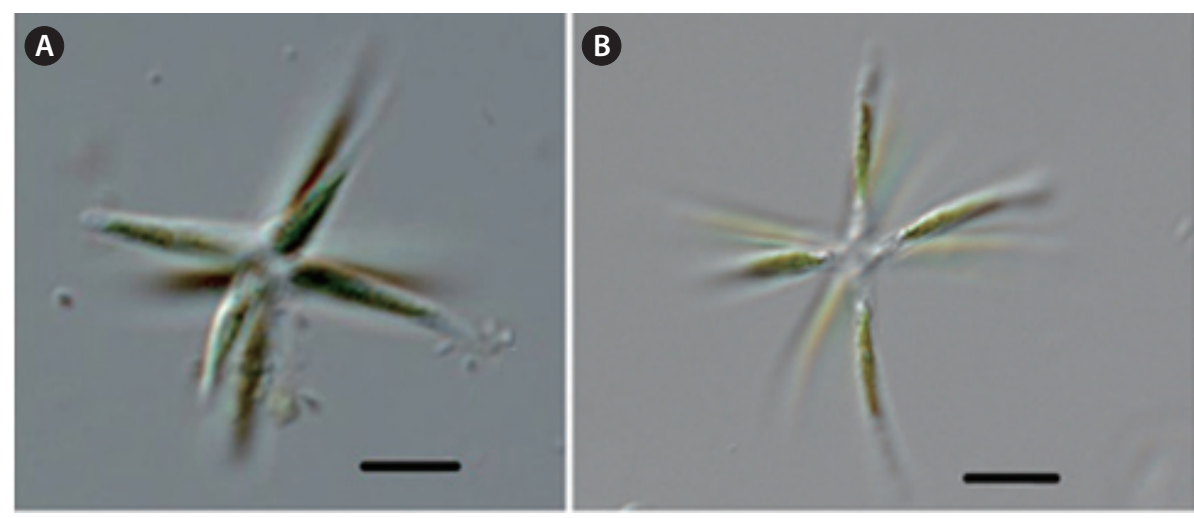

Fig. 17. Actinastrum aciculare Playfair (A-B: each other colony). Scale bars, $10 \mu \mathrm{m}$.

radiatum var. emarginatum f. convoxum, $P$. biradiastrum var. glabrum, $P$. biwae, $P$. boryanum, $P$. boryanum var. brevicorne f. puncta, P. boryanum var. longicorne, $P$. boryanum var. perforatum, $P$. boryanum var. rugulosum, $P$. duplex, $P$. duplex var. asperum, $P$. duplex var. clathratum, $P$. duplex var. genuinum $\mathrm{f}$. convergens, $P$. duplex var. gracillirium, $P$. duplex var. punctatum, $P$. duplex var. reticulatum, $P$. duplex var. rotundatum, P. duplex var. rugulosum, P. glanduliferum, P. integrum, P. muticum var. crenulatum, P. napoleonis, P. obtusatum, P. obtusum, P. simplex, P. simplex var. duodenarium, P. angulosum, P. tetras, P. tetras var. exisum, P. tetras var. tetraodon. Among these, 5 taxa have been reported by Chung (1970). However, this reported needs to be reevaluated because it is not peer-reviewed journal article, but it is only the doctorate thesis of Chung (1970). Futhermore, some taxa needs to be merged reconcile synonyms.

The genus Coelastrum of the family Coelastraceae is distributed in cosmopolitan areas and various aquatic habitats. 23 taxa have been reported by Komarek and Fott
(1983), and 49 taxa by Gury and Guiry (2013). However, 9 taxa (i.e., C. asteroideum, C. cambricum, C. cambricum var. intermedium, C. elegans, C. microporum, C. proboscideum, C. reticulatum, C. sphaericum) have been reported in Korea. Among them, there needs to be exception 1 taxon by Chung (1970), because this is not merely a journal but his doctorate thesis.

\section{CONCLUSION}

The families Hydrodictyaceae and Coelastraceae of order Chlorococcales were investigated 5 genera, 29 species, and 17 varieties. Among them, 8 taxa were newly recorded in Korea; 1) Family Hydrodictyaceae: P. asymmetricum, $P$. boryanum var. campanulatum, 2) Family Coelastraceae: Actinastrun aciculare, A. hantzschii var. subtile, Coelastrum indicum, C. microporum var. octaedricum, C. morus, C. pulchrum. 


\section{ACKNOWLEDGMENTS}

This work was supported by a grant from the National Institute of Biological Resources (NIBR), funded by the Ministry of Environment (MOE) of the Republic of Korea (NBIR No. 2013-01-001).

\section{LITERATURE CITED}

Archer W. 1868. The vast majority are short notes on desmids collected in Ireland. Quarterly Journal of Microscopical Science II 8: 65.

Bohlin K. 1897. Die algen der ersten Regnell'schen expedition. I. Protococcoideen. K. Svenska Vetenskaps- Akademien Förhandlingar 23: 3-47. (in German)

Bold HC, Cronquist A, Jeffey C, Johnson LAS, Marguilis L, Merximiller H, Takhtajan AL. 1978. Proposa (10) to substitute the term phylum for division for groups treated as plants. Taxon 27: 121-122.

Braun, A. 1855. Algarum unicellularium genera nova vel minus cognita, I-III. W Engelmann, Leipzig. (in German)

Chodat R. 1902. Algues vertes de la Suisse. Pleurococcoïdes ChroolépoïdesBeiträge Kryptogamenflora der Schweiz. Band I, Heft 3. Berne: Druck und Verlag von K-J. Wyss, Libraire-Éditeur. (in Latin)

Chung J. 1970. Taxonomic study on freshwater algae in Youngnam area. PhD Dissertation. Kyungpook National University, Daegu, Korea. (in Korea)

Chung J. 1974. A study on the a few species of the freshwater algae in Korea. Kor J Plant Biol 17: 175-177. (in Korean with English abstract)

Chung J. 1978. A study on freshwater algae in Korea. Korean J Limnol 11: 39-42. (in Korean with English abstract)

Chung J. 1981. Freshwater algae on Chang-nyeong county area. (Around Bugok hot spring). Bull Kor Assoc Conserv Nat 3: 369-381. (in Korean with English abstract)

Chung J, Kim HS. 1992. Freshwater algae on Gunwi-county area. J Kyungpook Natl Univ 52: 91-104. (in Korean with English abstract)

Chung J, Kim SD, Lee KS. 1972. Freshwater algae from Jejudo Island. Korean J Limnol 5:15-31. (in Korean with English abstract)

Chung J, Kim YJ. 1991. Freshwater algae on Seongju county area. J Kyungpook Natl Univ 51: 33-58. (in Korean with English abstract)

Chung YH. 1968. Illustrated encyclopedia of fauna and flora of Korea, Vol. 9: Fresh-Water Algae. Samhwa Publishing, Seoul. (in Korean)

Chung YH, Chang YK. 1957. A study on Euglena in the area of
Seoul (II). Univ Seoul Coll Thesis Sci Nat 5: 119-128. (in Korean with English abstract)

Chung YH, Lee K. 1978. A study on the Microflora of the Han River (IX): taxonomy of phytoplankton and environmental conditions in Paldang Dam reservoir. Proc Coll Nat Sci Seoul Natl Univ 3: 97-129. (in Korean with English abstract)

Emoto Y, Hirose H. 1942. Studien uber die thermalflora von Japan XXT. Thermal algen aus heissen Quellen von Kokaido, Korea. Chosen Nat Hist Soc 9: 130-143. (in Japanese)

Fott B. 1977. Taxonomische Übersicht der Gattung Actinastrum und der Unterfamilie Actinastroideae (Scenedesmaceae). Preslia 49: 1-8. (in German)

Gury MD, Guiry GM. 2013. AlgaeBase. World-wide electronic publication, National University of Ireland, Galway. http://www.algaebase.org. Accessed 15 June 2013.

Hegewald E, Schnepf E. 1979. Pediastrum privum (Printz) Hegewald comb. Nova. Arch für Hydrobiol Suppl 56 Algol Stud 22: 24-28.

Hegewald E, Yamagishi T. 1994. Pediastrum asymmetricum Yamagishi et Hegewald, a new species from Japan and some notes on accompanying Pediastrum taxa. Nova Hedwigia 59: 77-95.

Hindak F. 1977. Studies on the Chlorococcal algae. Chlorophyceae. Vol I. Biologické práce 23. VEDA Publishing House Slovak Academy of Sciences, Bratislava.

Hirose H, Yamagishi T. 1977. Illustration of the Japanese Freshwater Algae. Uchida Rokakuhe, Tokyo. (in Japanese)

John DM, Tsarenko PM. 2002. Order Chlorococcales. In: The Freshwater Algal Flora of the Britain Isles. An identification guide to freshwater and terrestrial algae (John DM, Whitton BA, Brook AJ, eds). Cambridge University Press, Cambridge, pp 327-409.

Kang SW. 1967. The studies on the limnological survey in Seodun - stream which flows near the farm campus, in the college of agriculture, Seoul National University. $\mathrm{PhD}$ Dissertation. Seoul National University, Seoul, Korea. (in Korea)

Kawamura T. 1918. Nippon-Tansui-Seibutsugaku (I). Mohanahusa, Tokyo. (in Japanese)

Kenrick P, Crane PR. 1997. The origin and early diversification of land plants: A cladistics study. Smithsonian Institution Press, Washington, DC.

Kim CS, Chang YK. 1958. A study on the freshwater red algae of Korea. J Biol Sci 3: 14-16. (in Korean with English abstract)

Kim HS, Chung J. 1993. Freshwater algal flora of natural swamps in Changnyong county. Korean J Limnol 26: 
305-319. (in Korean with English abstract)

Kim HS, Kim YJ, Park JW, Chung J. 1994. Unreported freshwater algae in Korea. Kor J Plant Biol 37: 131-140. (in Korean with English abstract)

Kim MR, Chang YK. 1997. Taxonomic Studies on some species of Pediastrum Meyen in Korea. Algae 12: 159-165. (in Korean with English abstract)

Kim YJ. 1994. The taxonomic and ecological study of phytoplankton in the Lake Pomun and Tokdong, South Korea. PhD Dissertation. Kyungpook National University, Daegu, Korea. (in Korean)

Kim YJ. 1996. Ecological study of phytoplankton community and trophic states using indicator in Lake Paldang. Korean J Limnol 29: 323-345. (in Korean with English abstract)

Kim YJ, Kim HS. 2012. Algal flora of Korea: Chlorophyta, Chlorophyceae, Chlorococcales I: Micractineaceae, Botryococcaceae, Characiaceae, Hydrodictyaceae. NIBR, Ministry of Environment, Incheon.

Kim YJ, Kim HS, Chung J. 1991. Seasonal variation of phytoplankton in Lake Tokdong and Pomun. Korean J Limnol 24: 251-263. (in Korean with English abstract)

Kim YJ, Lee JH. 1995. Structure of phytoplankton communities of six Dam lake in the Nakdong river system. Korean J Limnol 29: 347-362. (in Korean with English abstract)

Komarek J, Fott B. 1983. Chlorophyceae (Grünalgen) Ordnung: Chlorococcales. In: Das Phytoplankton des Süßwassers. Die Binnengewässer XVI, 7(1) (HuberPestalozzi G, ed). Schweiz Verg, Stuttgart. (in German)

Komarek J, Jankovska V. 2001. Review of the Green Algal Genus Pediastrum; Implication for Pollen analytical research. Bibl Phycol, Vol. 108. J Cramer, Stuttgart.

NIER. 2013. Water Information System of the Ministry of Environment. http://water.nier.go.kr/main/mainContent. do. Accessed 20 June 2013.

Parra OO. 1979. Revision der Gattung Pediastrum Meyen (Chlorophyta). Bibliotheca Phycologica, Vol. 48. J Cramer, Stuttgart. (in German)

Playfair GI. 1917. Australian freshwater phytoplankton. (Protococcoideae). Proc Linn Soc New South Wales 41: 823852.

Prescott GW. 1962. Algae of the Western Great Lakes Area. Wm C Brown Company Publisher, Dubuque.

Round FE. 1971. The taxonomy of the Chlorophyta II. British Phycol J 6: 235-264.
Schmidle W. 1893. Beiträge zur algenflora des Schwarzwaldes und der Rheinebene. Berichte Naturforschende Gesellschaft zu Freiburg, Vol. 7. pp 68-112. (in German)

Skvortzow BW. 1929. On some diatoms from Seiko lake of Chosen, Japan. J Chosen Nat Hist Soc 8: 9-14.

Skvortzow BW. 1932. Desmids from Korea, Japan. Philipin J Sci 49: 147-158.

Sodomková M. 1972. Taxonomische Übersicht der Gattung Coelastrum Nägeli. Acta Universitatis Carolinae Biologica1970, Praha, pp 481-512. (in German)

Sulek J. 1969. Taxonomische Übersicht der Gattung Pediastrum Meyen. In: Studies in Phycology (Fott B, ed). Schweizerbart, Stuttgart, pp 197-261. (in German)

Tell G. 1979. Chlorophyceae d'eau douce rares et nouvelles de la epublique Argentine. Rev Algol NS 14: 39-48. (in Spanish)

Turner WB. 1892. Algae aquae dulcis Indiae Orientalis. The fresh-water algae (principally Desmidiaceae) of East India. Kungliga Svenska Vetenskaps-akademiens Handlingar, Stockholm, 25: 1-187. (in Swedish)

Ueno M. 1940. Limnological survey in North Korea. J Limnol 11: 96-107. (in Japanese)

Ueno M. 1942. Introductory account of the biological survey of inland waters of Northern Tyosen (Korea). Jap J Limnol 11: 96-107. (in Japanese)

West W, West GS.1896. Algae from central Africa. Journal of Botany, British and Foreign 34: 377-384.

Wille N. 1924. Süsswasseralgen von der deutschen SüdpolarExpedition auf dem Schiff “Gauss”. In: Deutsche Südpolar-Expedition 1901-1903, Vol. 8 (von Drygalski E, ed). G Reimer, Berlin, pp 373-495. (in German)

Wittrock V, Nordstedt CFO. 1883. Algae aquae dulcis exiccatae praecipue Scandinavicae. Fasc 5: 235.

Wolle F. 1887. Freshwater Algae of the United States (exclusive of the Diatomaceae). Vols. Land 2. Comenius Press, Bethlehem, PA.

Yamagishi T, Akiyama M. 1984-1997. Photomicrographs of the Freshwater Algae. Vol. 1-10. Ukida Rokakuho, Tokyo.

Yamaguchi H. 1941. The Desmids of the bog-lake Daitaku of northern Korea. Jap J Limnol 11: 117-129. (in Japanese)

Yamamoto K. 1941. The plankton of lake Fusenko of Northern Korea. Jap J Limnol 11: 108-116. (in Japanese)

Yang HJ, Chung J, Song SD. 1981. Limnological studies of Nakdong River in Korea. Verh Internat Verein Limnol 21: 894-907. 